(26.

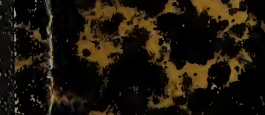

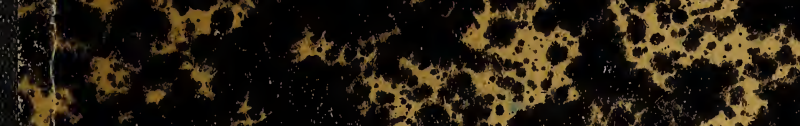

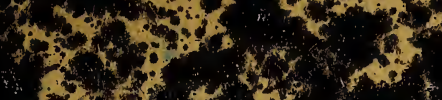

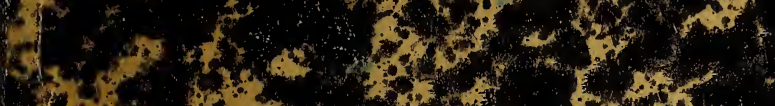

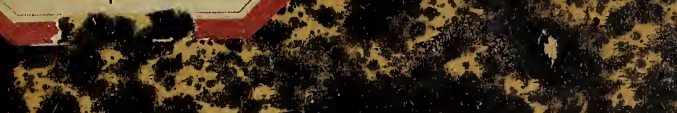

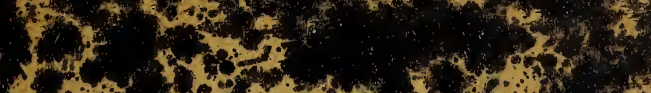
2 4.2 $x+y^{2}$

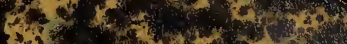

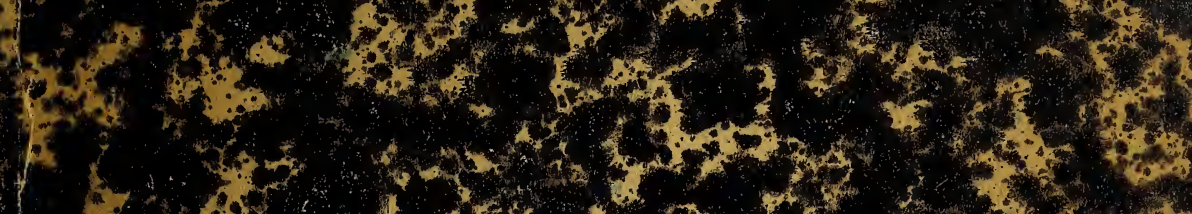

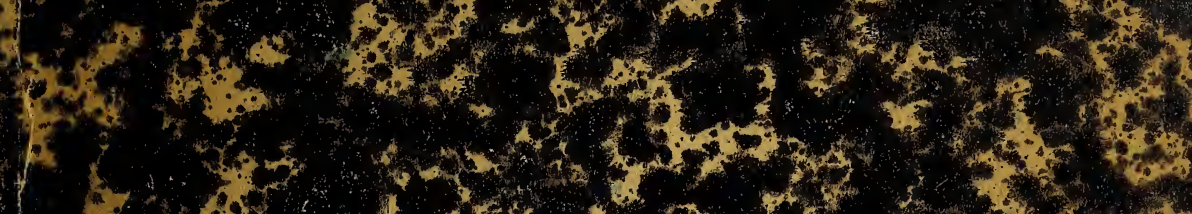

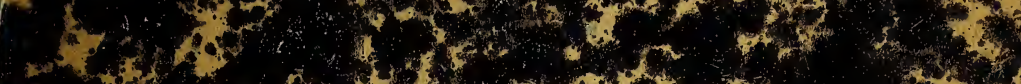

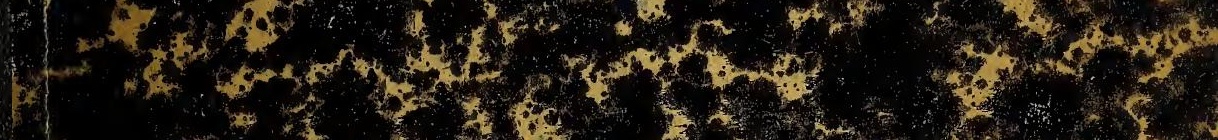

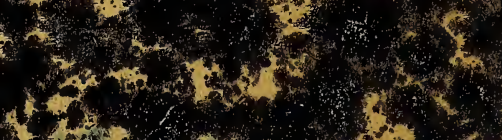

(n)

s.

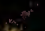

30

(2) $x^{2}$

$2 x+4$

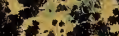

$+\frac{1}{3}, \frac{1}{2}$

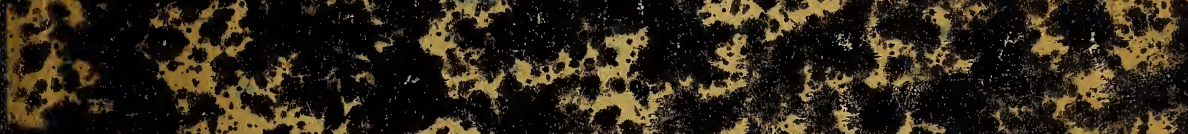

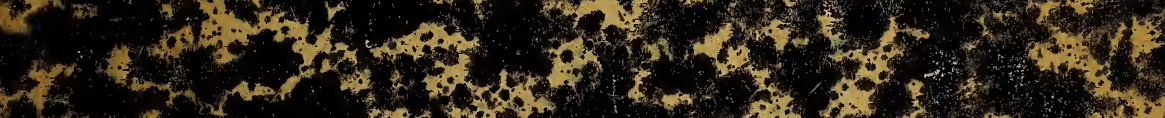
$x^{2}+x^{2}+x^{2}+x^{2}$

s M sat $x^{3}+1$

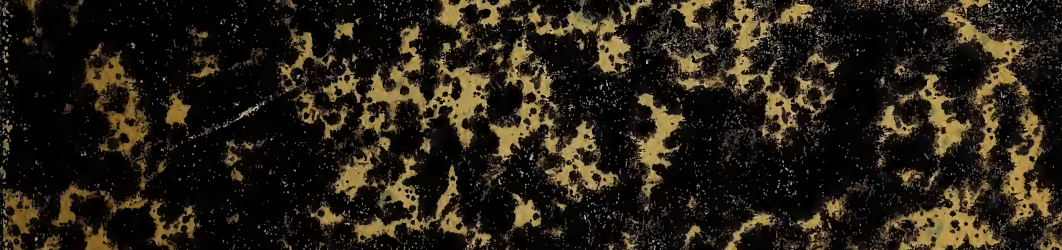




Some Helps for the

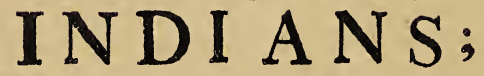

Shewing them how to Improve their Natural Reafon, to know the true God, and the Chriftian Religion.

$$
\begin{aligned}
& \left\{\begin{array}{l}
\text { 1. By leading them to fee the Divine } \\
\text { Authority of the Scriptures. } \\
\text { 2. By the Scriptures, the Divine } \\
\text { truths neceffary to Eternal fal- } \\
\text { vation. }
\end{array}\right\} \\
& \text { B B } R \text { Y Y A M P E I R SON } \\
& \text { Paftor of the Church at Branford. }
\end{aligned}
$$

Examined and approved by that Experienced Gentleman (in the Indian Language ) Captain FOHN SCOT.

$C A M B R I D G E$ : Printed for Samuel Green, 1658. 

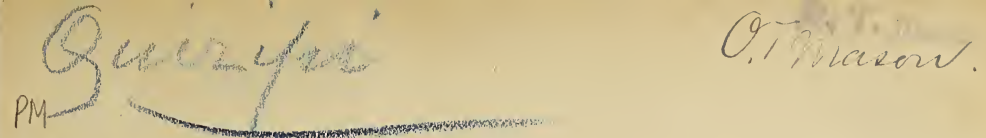

\section{A CATECHISM}

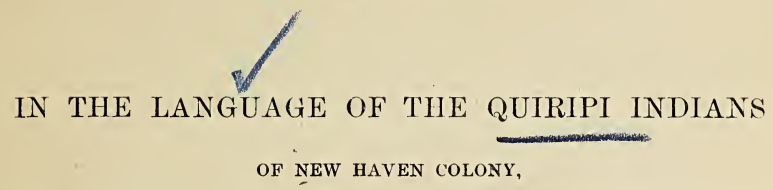

BY THE REV. ABRAHAM PIERSON.

REPRINTED FROM THE ORIGINAL, EDITION, CAMBRIDGE, 1658.

WITH AN INTRODUCTION,

BY J. HAMMOND TRUMBULL.

FROM THE COLLECTIONS OF THE CONNECTICUT HISTORICAL SOCIETY, VOL. II.

HARTFORD :

PRINTED BY M. H. MALLORY \& CO.

1873.

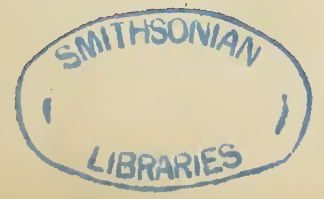


One Hundied Copies. 


\section{SOME HELPS FOR THE INDIANS:}

BY THE REV. ABRAHAM PIERSON.

The Rev. Abraham Pierson, ${ }^{1}$ who is said to have been a native of Yorkshire, was educated at Trinity College, Cambridge, receiving his bachelor's degree in 1632 . He came to New England in 1640; was admitted to the Boston church, September 5th in that year, and in November became the minister of a company about to remove from Lynn, Mass., to settle a plantation on Long Island, at Southampton. After the annexation of Southampton to Connecticut in 1644, Mr. Pierson, with part of his church, preferring the jurisdiction of New Haven, joined some planters from Wethersfield who had procured a grant of lands at Totoket, afterwards named Branford. Here a new church was organized, and Mr. Pierson was chosen its pastor. He remained at Branford until the union of New Haven colony with Connecticut, under the charter of 1662, again brought him under a government in which church membership was not an indispensable qualification for civil office and the privileges of a freeman. In 1667, he once more removed, with a majority of the Branford church, to New Jersey, and became the first minister of Newark, where he passed the remainder of his life. He died, August 9, 1678: "a godly, learned man," as Governor Winthrop testifies.

In September, 1651, when he had been living some seven years at Branford, the Commissioners of the United Colonies

${ }^{1}$ On the title-page of his Catechism the surname is Peirson, and so in the Records of New Haven Colony, 1653-1662, passim. But his autograph, (engraved for Mr. Hoadly's second volume of New Haven Colo-

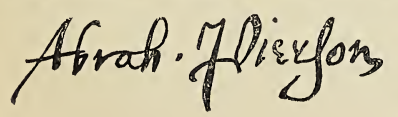
nial Records, p. 469, ) has Pierson, and the name was so written by his son, the first Rector of Yale College. 
wrote to the Corporation in London for Propagating the Gospel in New England, that "Mr. Blinman, Mr. Pierson, \&c., are studying the language" of the Indians, "that they may the better treat with them concerning the things of their peace;" and in a letter to the Rev. John Eliot, September 12th, the Commissioners inform him that "Mr. Higginson [of Guilford] hath spent some time formerly about the Indian language, and Mr. Pierson hath done the like, and continueth with much seriousness therein." ${ }^{1}$ In 1653 , he was allowed $£ 12$ "towards his charge and pains in fitting himself to teach the Indians," 2 and the next year this allowance was increased to $£ 15 .^{3}$

In 1654, the Commissioners wrote, from Hartford, to the Corporation: "One Catechism [Mr. Eliot's] is already printed, and $\mathrm{Mr}$. Pierson is preparing another to suit these southwest parts, where the language differs from theirs who live about the Massachusetts." ${ }^{4}$

Mr. Eliot's Catechism, printed in 1654, at the charge of the Corporation in London, was written in the dialect of eastern Massachusetts, and he was now translating the Bible into the same dialect. The Commissioners from the southern colonies -Connecticut and New Haven-were desirous that a portion of the funds provided for propagating the gospel in New England should be so expended as to benefit Indians of other than the Massachusetts tribes; and Mr. Eliot was advised, in 1654, to "improve the best helps the country affords for the Indian language, that, if it may be, the southwest Indians (some of whom, as we are now informed, desire help both for reading and to be instructed in the things of God and Christ) may understand and have the benefit of what is printed." 5

When the Commissioners met, at Plymouth, in September, 1656 ,

"A letter from Mr. Pierson, of Branford, dated the 25th of August last, was read, and some part of a Catechism by him framed and propounded, to convince the Indians, by the light

${ }^{1}$ Records of the Commissioners, in Hazard, ii. 178, 186.

${ }^{2}$ Ibid., 303. $\quad{ }^{3}$ Ibid., 326. $\quad{ }^{4}$ Ibid., p. $313 . \quad{ }^{5}$ Ibid., p. 316. 
of nature and reason, that there is only one God who hath made and governeth all things, \&c., was considered; and the Commissioners advised that it be perfected, and turned into the Narragansett or Pequot language, that it may be the better understood by the Indians in all parts of the Country. And for that purpose they spake with and desired Thomas Stanton to advise with Mr. Pierson about a fit season to meet and translate the same accordingly, without any unnecessary delay, that it may be fitted for and sent to the press: and they promised him due satisfaction for his time and pains. It was agreed that Mr. Pierson shall be allowed fifteen pounds for the pains he shall take in this work the year ensuing."

The translation was completed before the next meeting of the Commissioners, September, 1657. They wrote to the Corporation : ${ }^{1}$

"We have also sent you . . . Mr. Pierson's Catechism, which we have desired Mr. Ince to transcribe, whom you may please to improve to overlook the press, to prevent mistakes, especially of the Indian. We do desire the work may be expedited, and that 1,500 copies be sent hither to us by the first opportunity."

Jonathan Ince, who graduated at Harvard College in 1650, was commended by Eliot as "a godly young man, a scholar who hath a singular faculty to learn and pronounce the Indian tongue." 2 He and young Thomas Mayhew-the missionary of Martha's Vineyard-took passage for England in Garrett's ship, which sailed in November, 165\%, and was lost, with all on board, at sea.

Next spring, the Corporation, in their letter to the Commissioners, wrote from London :

"As for Mr. Pierson, we concur with you concerning his fitness and ability for the Indians' spiritual good, and for the Catechism mentioned in your letter, of his composing for their use and instruction, which we should have taken care to have printed according to your desire, . . . but we fear it is miscarried, being sent, as we understand, in Mr. Garrett's ship, which is yet missing: and therefore, we intreat you to send it over by the first opportunity." 3

In September, 1658, Mr. Pierson had prepared another copy

${ }^{1}$ Records of the Commissioners, in Hazard, ii. 377.

${ }^{2}$ Felt's Eccles. Hist. of N. E., ii. $163 . \quad{ }^{3}$ Hazard, ii. 390. 
of the Catechism for the press, and delivered it to the Commissioners in session at Boston. "Upon further consideration, in regard of the hazard of sending, and difficulty of true printing it without a tit overseer of the press, by one skilled in the language," the Commissioners decided to have it printed at Cambridge, instead of in England as at first proposed. ${ }^{1}$ They "hoped it would be finished within three months."

The first sheet (of sixteen pages) was printed, at the Cambridge press, before December 28th-in season to be sent to England, with letters of that date from Mr. Eliot and Governor Endecott to the Corporation. Another letter of Eliot's, written December 10th, enclosing notes of exhortations delivered by Christian Indians of Natick, on a day of fasting, November 15 th, was forwarded by the same conveyance, or at nearly the same time. May 7, 1659, the Corporation wrote to the Commissioners :

"We have thought good to print your last letter [of Sept. 22d], with two other letters received from $\mathrm{Mr}$. Endicott and Mr. Eliot; as also, the Indians' Exhortations, and the sheet of Catechism composed by Mr. Pierson; all which are printed for publick satisfaction." 2

They were printed in a small-quarto tract of forty-eight pages (thirteen of which are not numbered), with the following title:

A further Accompt / of the Progreffe of the | GOSPEL | amongt the INDIANS | IN | NEW-ENGLAND, | AND | Of the meanes ufed effectually to advance the fame. | SET FORTH | In certaine Letters fent from thence declaring a / purpofe of Printing the Scriptures in the | Indian Tongue into which they are already | Tranflated. | With which Letters are likewife fent an Epi- | tome of fome Exhortations delivered by the $I n$ - | dians at a faft, as Teftimonies of their obedi- | ence to the Gofpell. | As alfo fome helps directing the Indians how to / improve naturall reafon unto the knowledge | of the true God. I - I LONDON, Printed by $M$. Simmons for the Corpo- | ration of Nexe-England, 1659 .

An introductory epistle "To the Christian Reader," by the Rev. Dr. Edward Reynolds, dated 1 April, 1659, commends Mr. Pierson's work, as

${ }^{1}$ Hazard, ii. 392.

${ }^{2}$ Ibid., 403. 
" likely to be, by the blessing of God, of singular use to the natives there, and a very proper and necessary course for those to take who would convert and perswade Pagans to beleeve the Truth. ... The reason why there is so short and imperfect a specimen given of it is, because the ships came away from New-England, before any more of the Copy was wrought off from the Presse."

The tract is made up as follows: Title, verso blank; "To the Christian Reader," 7 pp. n. n. (A2 to recto of B; verso of $\mathrm{B}$, blank); Letter from the Commissioners of the United Colonies, 2 pp. (B2; the verso numbered as page 1); "A Letter from Mr. John Eliot," pp. 2, 3 ; "A Letter from John Endicott Esq.," pp. 4, 5; "Here follows another Letter from Mr. John Eliot," pp. 6, 7; "Here followeth a Briefe Epitome of such Exhortations," \&c., pp. 8-19 (ending on verso of D3); and a "Postscript" (D4; verso blank). Then, with a special title-page, a reprint of the first sheet of Mr. Pierson's Cat'chism, pp. 22-35 (E1 to verso of F3) with his introduction "To the Reader." The title-page corresponds with the Cambridge original, except in the imprint, "LoNDon, Printed by M. Simmons, 1659." On the recto of F4 is a "Postscript" to the tract, introducing a certificate of "Charles Chauncy, Præsident of Harvard College, in Cambridge," to the proficiency of two of the Indian pupils at the grammar school in Cambridge. The verso of F4 is blank.

The impression of the Catechism at Cambridge was not completed till five or six months after the first sheet was reprinted in London. In September, 1659, the Commissioners wrote, from Hartford:

2. "We have ordered Mr. Usher to send you forty copies of Mr. Pierson's Catechism, if finished before the ship set sail ; but fear, by reason of Mr. Pier'son's sickness, ${ }^{1}$ the work may have been retarded, and we and you suffer a disappointment." 2

\footnotetext{
${ }^{1}$ Rev. John Davenport, writing to Gov. Winthrop, from New Haven, July 29th, mentions the dangerous sickness of Mrs. Pierson. The next week, August 5th, he writes that her condition is hopeful, but " $\mathrm{Mr}$. Pierson hath been touched" with the prevailing epidemic: he "wisely took the physic in the beginning, and will, I hope, do well."-4 Mass. Hist. Coll., vii. 501, 503, 504.

${ }^{2}$ Hazard, ii. 404.
} 
At the same session, the treasurer's "account of the Indian Stock" has an entry of the payment

"To Mr. Green, in part, for printing the Psalms and Mr. Pierson's Catechism, $L 40.00 .00$."

Only two copies of this Catechism are known to the editor of the present reprint. One of these is in the library of Mr. James Lenox of New York; the other is in the British Museum. The title-pages of the two differ, in several particulars. That of Mr. Lenox's copy - which is proved, by its agreement with the English reprint of the first sheet, to be the earlier-has a border, of the acorn pattern. The other has no border; the lines are longer, and the page less compact. After the title proper, ending with the words "Eternal Salvation," the Museum copy has-

By | ABRAHAM PEIRSON | Paftor of the Church at Brandford. $\mid$ - I Examined and approved by that | Experienced Gentleman (in the $I n$ - | dian Language) Captain | JOHN SCOT. I- - CAMBRIDGE: | Printed. for Samuel Green, 1658.

Here no reference appears to the Commissioners of the United Colonies, and the imprint, it may be observed, is "for" (not "by) Samuel Green." Of Captain John Scott, nearly all that is known may be read in Dr. Palfrey's History of New England, vol. ii. pp. 564 569, note. He was on Long Island in 1654, and was arrested by the Dutch authorities, as a suspected person. ${ }^{1}$ Before 1660, he had caused the people of Southampton-where Pierson had formerly been settledmuch embarrassment, by claiming to have obtained from the Indians large grants of land, for which he executed numerous conveyances to varions parties. He was in England in October, 1660, and may have carried with him copies of Mr. Pierson's Catechism, printed the preceding year. In 1663, he was an active and unscrupulous agent of the proprietors of Narragansett lands conveyed by Indians to Major Atherton and his partners, and succeeded in obtaining from Charles II. an assurance to these proprietors, of "the full and peaceable enjoyment of their said country," the recently granted charter

${ }^{1}$ Brodhead's Hist. of N. Y., i. 579. 
of Rhode Island notwithstanding. ${ }^{1}$ The second title page of the Catechism, on which he is named as an "experienced gentleman," may have been prefixed to part of the edition-to all the copies, perhaps, which were sent to England about the time of the Restoration, and subsequently,-with the knowledge of Mr. Pierson and the Commissioners; or the substitution may have been Scott's own device, to give himself, in London, a certificate of position and character, and perhaps add weight to his statements in support of the title of the Narragansett proprietors and of his own claims to lands for which he had procured deeds from Indians on Long Island.

The advice of the Commissioners, that the Catechism should be "turned into the Narragansett or Pequot language, that it may be the better understood in all parts of the country," was not followed. The version is in the dialect which was the most familiar to Mr. Pierson during his ministry at Branford -that of the QUIRIPI Indians, who lived near Long Island Sound, from Guilford westward, to and beyond the west bounds of Connecticut. Block, the Dutch captain who sailed through the Sound in 1614, found a band of the "Quirepeys" near the mouth of Housatonic River. ${ }^{2}$ The name, which means 'long water,' was, probably, a general one, like Niantic for the " river-point" bands, and Nipmuck for "freshwater fishing" tribes. The adjective quir' $\iota$ ' long' is the equivalent of the Narragansett and Mohegan quinni, Connecticut River and Nipmuck quilli. Roger Williams wrote the names of these Indians, collectively, "Quinnipiěuck." The first settlers of New Haven bought lands of one of the Quiripi bands or petty tribes, and the name of their purchase appears as Quillipieck, Quinnipiock, \&c., as scribe or interpreter caught the sound from Indians of one or another local dialect. ${ }^{3}$ By

\footnotetext{
${ }^{1}$ Arnold's Hist. of R. Island, i. 383-385; N. Haven Records, ii. 499.

${ }^{2}$ De Laet, Nieuwe Wereldt, b. iii., c. 8 ; in the (Latin) edition of 1633, Querepees; Brodhead's Hist. of New York, i. 56, 57.

${ }^{3}$ In Davenport and Eaton's letter of March 12, 1637-8 (in 3 Mass. Hist. Coll., iii. 165) it is Quillypieck; in the first recorded agreement with the Indians, November, 1638 (Thomas Stanton interpreting), Quin-
} 
this Branford and New Haven tribe, the name of 'long water' -which may have originally belonged to Long Island Soundwas appropriated to the harbor of New Haven and the estuary of Quinnipiac and Mill rivers which opens into it.

Of the inflectional and conjugational forms of the Quiripi language, or of the structural peculiarities of Indian languages in general, Mr. Pierson evidently knew little. In the translation of his catechism he frequently transferred to an Indian. word the connotation of the corresponding word in English, and reduced English verbal metaphors to their literal and material elements. Thus, for ' to punish,' ' to correct,' and for "God's punishing will" (p. 26) he employs the Indian verb tatággaman, meaning 'to strike,' 'to beat,' hence 'to punish by beating,' not otherwise. He derived some help probably from the work of Eliot, whose versions of Genesis and Matthew were printed before November, 1658, and his first Catechism in 1654. But Eliot, with all his subsequently acquired mastery of the Indian language, could not have translated into it Mr. Pierson's preliminary demonstration of the being, unity, and excellence of God, so as to make it intelligible to the natives. Thomas Stanton, though an excellent interpreter in negotiations between the English and the Indians, was no dialectician, and "that experienced gentleman in the Indian language, Captain John Scott," cannot have rendered much assistance in this part of the work. Take the following, as an example of Mr. Pierson's method of "showing the Indians how to improve their natural reason." It is one of the answers (p. 12) to the question: "How do you prove that there is but one true God?"

"Because singular things of the same kind when they are multiplied are differenced among themselves by their singular properties ; but there cannot be found another God differenced from this, by any such like properties."

Or this (p. 24), as one of the proofs "that all singular things are governed by God's providence:"

"3. Because generals do subsist in singulars: and therefore,

opiocke; in the agreement of December 11th (John Clarke interpreting) Quinnypiock; elsewhere in the Records, Quinipieck, Quillipieck, \&c. 
if singulars were not preserved by God's providence, the generalls would perish with them."

The interlineation of the original English with the Quiripi version adds interest to the volume, by the illustration it affords of a method of religious instruction which many good men of Mr. Pierson's day agreed with Dr. Reynolds in regarding as "a very proper and necessary course for those to take who would convert and persuade pagans to believe the truth."

This Catechism is the only book printed in any Indian dialect of "these southwest parts." It is believed to be the first work of an author belonging to either of the two colonies (Connecticut and New Haven) that was printed in this country. It supplies linguistic material of some value to philologists, the Quiripi dialect having a place between the dialects of Massachusetts, Narragansett, and eastern Connecticut, and those of the Middle States; showing nearer affinity than other New England dialects to the (true) Delaware or Renapi of New Sweden. ${ }^{1}$

No pains have been spared to obtain an accurate reprint of the first edition. An experienced copyist was employed to make a transcript of the British Museum copy, and this was collated with the copy in the library of Mr. James Lenox, which he very kindly permitted to be used for that purpose, by the editor. The paging and signatures of the original are retained. No attempt has been made to correct the numerous typographical errors of the first edition, except where the error was so patent-as in the case of a turned letter or the intrusion of a wrong-font type-that to reproduce it would have seemed mere affectation of accuracy. The proportions of the page have been preserved, but by the use of larger type its size has been so enlarged as to adapt it to a modern octavo volume.

J. H. T.

\footnotetext{
${ }^{1} \mathrm{Mr}$. Pierson's version of the Lord's Prayer is reprinted, from this Catechism, and some peculiarities of the dialect are indicated in "Notes on Forty Algonkin Versions of the Lord's Prayer," in the Transactions of the American Philological Association for 1872 (and separately printed, Hartford, 1873; pp. 42-44).
} 



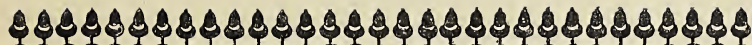
ॐ

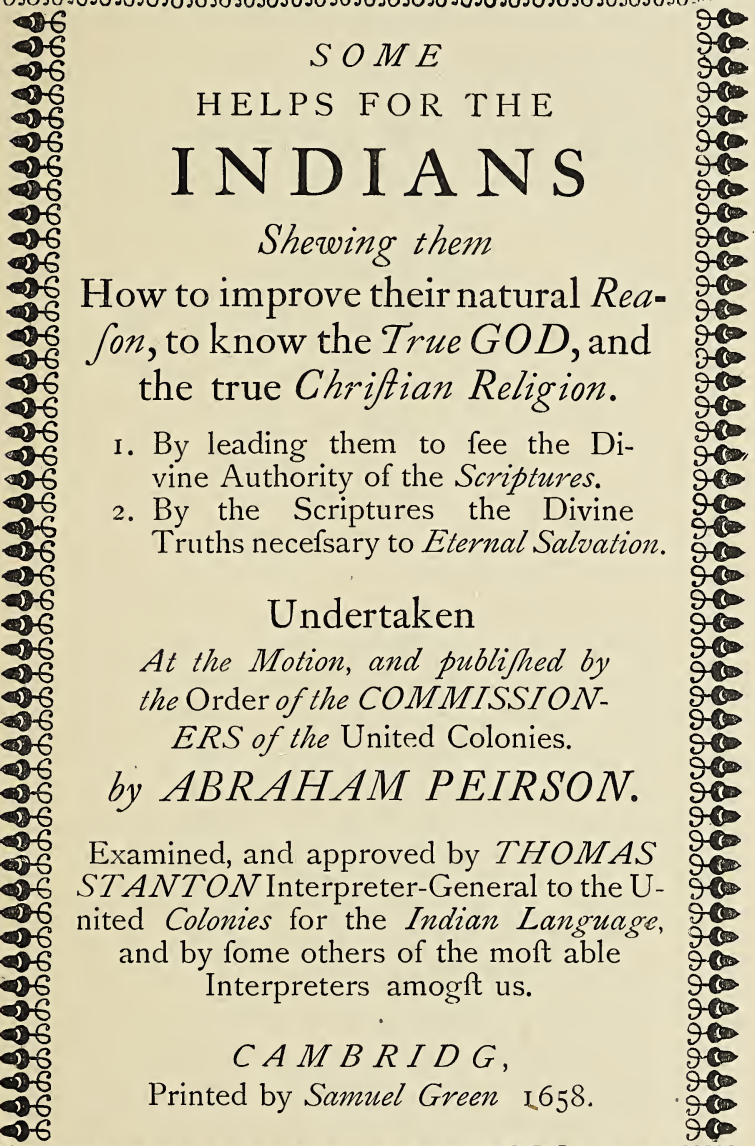

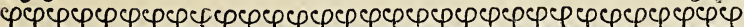

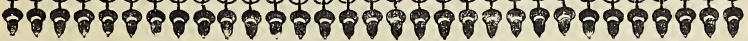





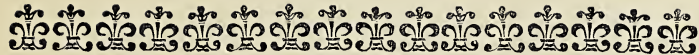

To the Reader.

(a) Fo have occafion to make ufe of this - Dook, may pleafe to obferve, that the (1) accute or long accent thus noted (á) fignifies that the fillable over which it is placed is to be pronounced long, the reft of the words be fhort, till the like, or a circumflex do regulate the fillables following. Words of two fillables moft frequently be not accented at all, being commonly of equal meafure, and hardly mifpronounced. Alfo, fundry times the prepofitions in, with, for, from, by, \&c: be Set after the Subftantives in the Indian and before them in the Englifh, that fo no harfhness (this caution remembred) may found in either. Likervife fometime a phrafe is ufed in the Indian, which word for word can hardly be rendred in the Englifh; but then, and ever, care is had that in every Sentence, and within the limits of every ftop, the Indian doth truely answer the Englifh. The Lord pardon, accept, and give fuccefs, that this may be an help towards the Spiritual good of Indian foules.

So prayes A. P. 


\section{[4]}

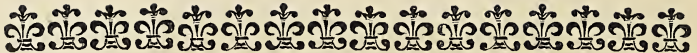

Some

helps

for POthfhe Aírenamáwetouwúngafh wutche
the Indians.

Eànsketámbawg ,

how to improve their

Okkekôodemúnganâuwaus natural

Reafon

ten auwárchan nêjek arumbáuwe penauwuawunk to know the only

wauhêan webe waugh wauwérhummat Man-
God, and the true Christian

do Iehovah, quah wérramâuwe Chriftianâureligion.

First

lead-

we routàfowank. Negónne fpe pummóoaing them to fee the divine Authowarránau nejek kenàwmen Màndowe tóuhrity of the Scriptures. kretáffowunk wutche God wuskwhéganfh. Secondly by the Scriptures the Néefeetetâuwe fpe God wuskwhéganfh màndivine Truths necesary dowaious wêrramauwúnganfh queraûhikka- muks re michéme kejâhiitawunk. 


\section{[4]

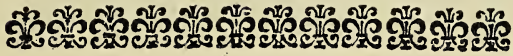

Some
Ofhrhe Aírenamáwetouwángarh wutche
the Indians. Eànsketámbawg , Okkekôodemúnganâuwaus how to improve their natural Reafon ten auwár Chan nêjek arumbáuwe penauwuawunk to know the only true

wauhêan webe waugh wauwérhummat ManGod,' and the true Chriftian do Iehovah, quah wérramâuwe Chriftianâureligion. we routà fowank. Negónne fpe pummóoawarránau nejek kenàwmen Màndowe tóuh-rity of the scriptures. kretáffowunk wutche God wuskwheganfh. Secondly by the Scriptures the Néefeetetâuwe fpe God wuskwhegganh màndivine Truths neceffary dowaious wêrramauwúngañh queraûhikikamuks re miChéme kejâhiitawunk. 



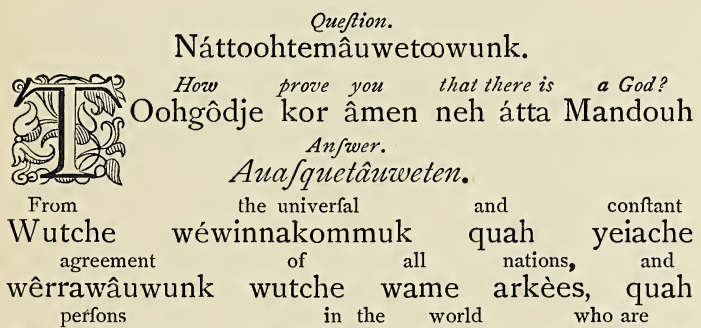
nkeetambâwg mittâuhkuk terre, owwànnak

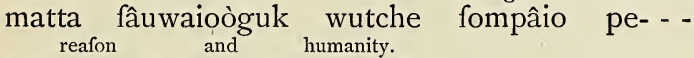

nauwáuwuk quah renôowunk.

For
Wutche ai akqúiiks chawgwunh we are
grounded kontamoawk fkeje nanfeêawk rénwawk róyfancies and opinions tammoúnganfh quah wàrramawòytammo- - unganfh matta wèrramattauòomuks wutche wame rènawawk, quah wegonje àffowunnamabut this notion nôofh: webe (youh eôytàmmoounk) neh

$$
\text { A3 Man }
$$




\section{[6]}

there is a God is common to all men. Nor

Mandoo nànnarwee re wâme rènawawk matta is it changed by the changes

áffowûnumôoanas fpe affowunnàmoúnganfh of times; therefore it muft

quompaious; nègouche youh paughke môuche arife from fome. light

fongème wutche chawgun nowèta weqúa-ai, which is common to all men. and that teou nannarwe re wame rènnawawk. quah youh light muft be either from $\underset{\text { tradition }}{\text { wequa-ai pahke mouche nukqúddee wutche }}$

af-híttewunk wutche pómmochawàthfhâufrom the firft parents of mankind wus wutche negoniíek oufhwâwog rèñawawk to all their posterity from re wame nejek wúttantewúngannôoawk wutche àntfeunganak, re àntfúnganak ouwànnak would not lye to their children matta pèperruwâgup re múkkraffoowúnganòas in a matter of so great

rame ifchâuwúnganak terre wutchio rio fhaiô importance; or from an inward light fhàrumauwúnganak; ux wutche ramiôuk we-implanted in the minds quàai ramekèzekekózzo ramee útteoitúmmœof all men bod] únganoo wutche wame rènnawawk fpe Iehovah himself. And that such a light nagum. Quah neh nenar wequàai útteamois in man naturally pètànguanau wàme rènnawawk renàmpaûwe ; appeareth by the feares that moufkème fpe wèz-faffawunganfh teous út- 


\section{[7]}

are in

all

men

when

teaompètáuguanau wame rénnawawk pókkatthey have done $\mathrm{y}^{\mathrm{t}}$ which they know to che rehit chawgun waughtaffoowawk matbe evill, though no man knoweth cheréwunk, mukko renna matta waughtamand upon extraordinary

móan, quah fkeje chechége móncharawa- accidents,

Thunder:

núnguotufh ahárrêmuks, arra Páddaquàh- Earthquakes, fights in the

hum, Quequanfh, mázzenúnguottufh kefefuk Aire, blafing Starrs \&c: which

terre, fquarrug arrákfak \&c: youh kakkoofhewes that they know there is a dumchàmo neh nejek wauhtânnau mouche milpower above the creatures, though kiffoowunk aufin keizhittifhànnuk, mukko they see him not, who will punifh matta naûwah, ouwun bitch arroutaûtak finn, and can do it when matcherêwunk, quah óm uttrên hanrúkkehe will. And this is

que roytaks. Quah youh mutche God Jehovah Secondly, from the beginning of all

Nézetataûwe, wafke noujàiitch wame things that have a dependant aiakquiiks, teous uttahhênau rambatfen being. $\quad$ For the things which had pummaiawunk. Wutche aiak quiiks téous noua beginning could not be caufe of their own jaiiggihhanfh, matta hom wâje pummaiawúnbeing, for that which is not cannot gano, wutche ne matta pummaynook matta act, nor could any thing hom rémanœ chaugun, matta hom chaugun 


\section{[8]}

bee
$\begin{gathered}\text { pummâio, } \\ \text { it muft }\end{gathered}$ $\underset{\text { from }}{\operatorname{paughke}}$ [môuchh] outàhhèamo noujaiewunk wutche chaugun nowêta perrewawhjaiohittit which is without beginning,

teou matta outchinoh [mehchu noujaiewunk] and therefore the firt being and

quah nè-wutche negonne pummayawunk quah

kezhúwan waje wutche wame ùnkatagganak beings.

pummayawúnganfh.

There was a firft man and a firft woman

Moh negônne ren, quah negônne kèrequaand a firf in every kind

bus, quah negónn rame wame achabwehittaof living creatures

wunk wutche púmpamantajek kezhitthaunak, but that firf man and woman [and] webe youh negônne ren quah kerequâbus, quah thore firft of al yôjek negonnijek wutche wame attchabre- kinds, living creatures

hittewúnganfh púmpamántejek kezhittifhañák could not make

themfelves

matta hom kezhúwâwk hoggaûwâwwo : therefore there was a firft being which negáuche moh negonne pummayhuad, youh abfolute funkaio [fambió] quah webe negamo tfe funkaio [fambió] quah webe negamo tfe and independent wutchaiô, quah matta chetamffennómanah that was before them all and chaugun, nôh moh akam wâme nejek, quah 
made them all, and upon whom kezhûwufhan wanne wame, quah fkeje youh all other beings depend. wame kattágganfh pummáyawūganfh korchétámfenak. Quah youh atta God Jehovah.

How can you know that there is Ob: Ten hôm kuttarváuhtaun ne atta a God, seing you never faw him, nor can Mando maetax kekenâuwah, matta hôm see him?

nauwo?

\section{I know}

\section{I}

have

a

An:
reafonable $\begin{gathered}\text { Nouwáuhtâun } \\ \text { foul, }\end{gathered}$ no wadjânaman though I never faw it, naunâuwe mittachonkq, mukko matta ne nauwah nor can fee it, The foul were not mátta hôm nauwo, Mittachonkq' matta hom a fpirituall fubftance if it could be feen rafhawrándowe pummâyawunk hôm naûwit with bodily eyes, and fo no fpe hoggâuwe fkefuks, quáh riò matta foul in like manner [God] were not a Spirit oútachonq'. Rio God matta rafhauwanif he could be feen with bodily eyes; do, om naûwit fpe hoggâuwe fkefuks ; and fo no God. quah rio matta Mando.

But no man can fully.

Ob: Webe matta howan nowêta hom tabâie know Gods nature therefore wauhtawn Fehovah vièzennk [arándoit] negouche no God? matta Mando?

$A n: \quad$ Youh matta nôfkommôenah, wutche 


\section{[Io]}

an inferiour

nature

cannot

che wómarremúggeree árrumâuit hommatta

fully underftand the things of an higher tabáíe wâuhtawn aiakquiiks wutche fháramand more excellent nature then úggefee quah arwenúngefee arrumbaúịt, aúfe itfelf

Beafts

cannot

nagamo hoggunk. Oppifhthamok hommatta underftand what man is, much wauhtàuóunau chawgun ren atta, fhare lefs how to plant, and govern

okkóffiffe ten reokkechan, quah foudamotâuCommon-weales or to become learned ôan kortafoôdomoúnganth; ux koodamanchan or fayl over wufkwhaganakre, ux feboghómman akkóm- the Seas \&c: For thefe things muk kathans \&c: Wutche yous aiakquiiks exceed capaci[remuks] árrookawáuwáunk nejek waúhtam- ties in like mannerman feeing himfelf mawúnganoó rio ren nauwun ewo hogga
to be made kezhean wutche arwenúguot arrumbâuwunk
then aûfinre oppifhimmok, quah youh matta wutche nagum hogga, pauhke mouthe pakadothat he who made him fuperiour

wan ne hôwan kezhuwus uwâio arrôokawah to beafts he noless above man, oppifhim, ewo aufinre arrôokawah renôok then man is above beafts; and àrra ren arrôokawant oppilhthim; quah therefore that $\mathrm{y}^{\mathrm{e}}$ full knowledg of his nègouche ne tabâio wauhtawunk wutche uwio 


$$
\text { [ I I ] }
$$

nature
mans [árrumàuoit $\begin{gathered}\text { exceeds } \\ \text { capacity. }\end{gathered}$ renna kitchfhantàmmoowunk.

Arethere many Gods? or is there but
Q. Shâraog Mandóak? ux webe átta pâ-
one
true pâfaguun wah wèrramat Fehovah?
There are not many Gods, there is only

An. Matta fharáou Mandoak, atta webe pâone true God.

fuk wah wèrremat Mando Jehovah.

$$
\text { How do you prove that, that there is but one }
$$

Q. To gouje korámen ne webe pâfuk wah werremat Fehovah? An. Wutche waiâiewunk tohódje nanfaîe- -

wok aiakquiiks wútche anféjekmuche nenar are multiplied is not to be found

kokkôodifhahéawk matta miffkommauwaû- -

$$
\text { in the nature of }
$$

oân râme àrumbâuwunk [arándoit] wutche

for
God; whings $\quad \begin{gathered}\text { the reafon } \\ \text { wajâiewunk } \\ \text { are multiplied }\end{gathered} \begin{gathered}\text { why } \\ \text { tohodje } \\ \text { is }\end{gathered} \begin{gathered}\text { fuch like } \\ \text { arfôauk } \\ \text { from }\end{gathered}$ are multiplied
from

aiakquiiks kokkôodifhhéauk atta wutche the fruitfulneffe of their caufes: hokkiffègowunk wutche wajaiwunganoas:
but
hath no webe God matta outáhe wajâiewunk wutche his being but is of himself uwâio pummaîewunk, webe wutche nagum hogga negôuche papafaqun. 


\section{[12]}

Becaufe fingular things of

2. Newutche nanfâioaks aiàkquiiks wutche the fame kind when they are multiplyed, nenar ârak nantféjek
are differenced $\begin{gathered}\text { kokkoodrifhthahettit, } \\ \text { them }\end{gathered}$ àchabiffohèawawk yarâuwe nàgamáuwo hog- felves by their fingular propertyes; gâuwo weêche nejek nánfeas artumbauhittawúnganfh webe muche hom matta fkôwah unanother God differenced from this by katak Mando achabizhéan wutche yôuh fpe any fuch like propertyes. chawgunfh arrâious àchabiffewúnganfh [ar- rambâmuks.

Becaufe its proper to 3. Nèwutche webe mohtantammim re God to do whatfoever he willeth; Jehovah uttèein hanharroytaks; hom fharehit many Gods they might will contrary things and Mandoak hom ópperrewórrantammock, quah one might be hindered by another nejek hom wówotamhittawawk rêan chawgun fo $\mathrm{y}^{t}$ he could not do what he would, which can not rio matta hom re kaddauwerèatteou hom matta ftand with the Omnipotency and toukranah weeche wame-keiztauwunganuk quah nature of God. arrandoit Jehovah.

$$
\text { But may there not }
$$

be many Gods: yet

Ob. Webe hom matta fhároog Màndoak: narfo that one as the cheefeft and greatef raio ne pafuk negónquafik quah oufewe kerik wutche wame? 


\section{[ I 3 ]}

An. Matta, $\underset{\text { muft }}{\text { wothe nuthe negónne pummáy- }}$ huad pauhke mutche nágamo utfe oúfewe quopream becaufe dependeth núnguofo [fquónguofo wutche matta rambátfênupon nothing, he refts not upon any perfon no chawgun, muche matta howáne káchetambut is all fufficient to him felf fenno webe wame tabbaio re nagamo hogga and to all things and all things quah wame re aiakquiiks; quah wame aiakquidepend upon him that which is not iks rambats'nnétaukq' chawgun nowéta matta abfolutely cheifert and above all nagámo utfe negónquafik quah árroukáffo wame cannot be God.

matta hom Jehovah.
Becaufe
the Effentiall

2. Wutche Mándowâious pummáyaûwo- propertyes of God are such us árwenunquefoûnganfh Jehovah nèarrious as cannot be given to any more then ar matta hom meríttonoufh unkatágganak re one. aufe pafuk.
What are
Qu. Chase
are peculiar
are peculiar
teous moutantamminough fohod how webe tfe?
There are many
An. Pharítchch' nen fwanch mifhom which include the rest.
teous mínnamok únkatágganfh.
perfections
are

I. Neh wame arwenunquefoúnganfh uttá- 


$$
\text { [r4] }
$$

in him originally, and cminently
mous rame ewo negónne, quah wuñafhíauwe
as in the firft faufe, from which
arh' rame negónne wajáiewunk, ten wutche ké-
heaven and earth and all things
fukq' quah ohke quah wáme aiakquiiks rame
them nejek uttúmmonúmmok nauweta châwgun good they haue that all perfectiwarréguk attáhéhit neh wame àrwejanúngueon are in infoúnganfh uttámous rame Jehovah wame árroufinitely the reafon why being kawâwe wajàiewunk to hodie pummáyawunk
and quah wurrégowunk wutche wame keíhigwushánnak fachwhúngankâuwo, atta wutche waìcaufe whereby they exift hath cōmunicated áiewund fpe teou poummàiomúauk maugamous fo much to them and no more, and youche re neiek quah matta wunk, quah hath made them capable of fo much keífheous neiek tabe àttumminúmmin youche and no more but [God] receiveth not quah matta wunk, webe Jehovah matta attüminanything from another but is a Spirit úmmo chawgun wutche únkatak, webe Rafhliving in him felf

fhâuunk pómpemautammin nagamo ewo terre, or of himfelf therefore God is not ux nagamo utfe negauche Jehovah matta fachlimmitted his ftrength is Infinite whúngankâuwo ewo milkiffewunk wame arrônkaffómo hanharróytaks utteréen kefukuk quah okke 


\section{[ I 5 ]}

earth

okkêak-terre

Infinite

his

Knowledg is

arrôukaffomo

ewo

wéwaughtâuwunk

he knoweth all

wame

waughtâun

the words,

wame aiakquiiks ;

and he feeth

he heareth all

padak wame ruwâuwunganth, quah wonaumen

all the works of all men in all

wame reúnganfh wutche wame renouh wame the World

his Goodnefs

is Infinite

mittâukuk tere, ouraiéwunk wame arrôkaffómo he is exceedingly good, he goes beyond all in ouffewe werrego, arrôukan wame wohwórgoodnefs he doeth good towards regewúnganak terre wauhwérrerêat rak' que wame keifheaus-hánnak, taûterêit Jehovah is infinite, he is every where in all the World wame arrôukaffómo wampfin wame mittauk filling all places and goes not remáffen wame ahapúmmuks, quah matta from place to place, as doth the creatures, his ahàntfe aû, arra rehit keizhíttihánnak uplife is Infinite, he pomantammewunk wame arroûkaffómo, ewo is Eternal, without beginning, and muche Micheme, matta nenóujaaíous, quah without end. matta éakquíno.

13. That the true God is

3. Neh wauh wérramat Mandouh muche perfectly bleffed in himfelf, alfufficient fonks waûwerrehea nâgamo utfe, Wame taof himfelf, he needs not fupply baio nâgamo utfe, matta querâuhikquo áirananamàmauetounk paíuwutche, Wutche, 


\section{[16]}

He knows all things at once

I. Waughtunk wame aiakquiiks, paffukùtte and together in all the World, without quah nàppe wawa mittâukuk terre, matta kedifcourfe by the Infinitenefs

ketokaûanak terre, fpe wame arroukawaûwunk of his Effence.

wutche ewo Pummàyawuk.

He willeth moft freely whatfoever

2. Wórrantámmo oùffewe narraûwe chawgun is good and fo perfectly that

nowêta warréguk, quah afonkkaíoùwe neh whatfoever he willeth is good chawgun wèrrantámmo muche warreguk, fo farr as he willeth it, and becaufe he wilrikqueque arróytak, quah wutche warranleth it, For [God] is fimply and Infitammen, Wutche Jehovah faíoo quah wame-arnitely good.

rôukovvauwe werrégo.

How do you prove that heaven and

Q. Ten hom wutche korámen neh kefuk' quah earth, and all things in them have ohke, quah wame aiakquiiks rame nejek out âhhethe original of their being

nau noujiewunk wutche nejek pummayawingafrom [God.]

no wutche Fehovah.

This followeth what was

A. Yowh nôfkonfòmo wutche chawgun faid before for we have proved àrwamacup negónne, wutche nôrramananas that God hath his being of neh Jehovah uttahe ewo pummàyawunk nahimfelf, and is but one therefore all gamo utfe, quah webe pafuk: negaûche wame unk 


\section{$[\mathrm{I} 7]$}

other

things

have

either

únkatágganoufh aîakquiiks uttâh-heauk nukqútte rame nejek hoggauwaûwo, ux rame nejek caufes

their being

from

wâujaiwûngano púmmayawúngano ewóunk him.

wutche.

Nannârwe

underftanding

of men

2. evince

wewâuhtâuwunk renouh

doth this, if

we con-

mouche mouskinnaman youh, hom nattâuan-

fider

any of

the creatures

particularly

tammokq polhfhe

wékontammówun

without

how

keizhittihannak

of mans body

within

tfáie, and

quah

pàquodjok, ten wame áchabehittewúnganfh of mans body, yea the leaft have their feveral

ren hok, nux akkôffiffous achachaberé- ufes, and are fitted to thofe ufes,

kataunâuous, quah oúftaunauauus yous aiaiewunby no

ganakre, matta fpe pépenauwantammewunk or induftry of their

ux affagafowunk wutche oùfhhlhawawog yet with fuch wifdom that the narra weeche rio wawàntammewunk neh aûfe more learned and more wife kòkkekôudamaûetifhannak quah arwe wawanmen are the more they admire it. tammok renou aufinre môzfantaminau youh. No wife man can imagine that Matta nawun wawantam hom roitammôan neh ftones and timber grew into an houfe, m'fanfh quah p'tuks terreginfh wejammuk re, 


\section{[18]}

by chance, or of themfelves, but that heanje, ux wutche nàgámâuwo, webe neh fome nkilfull artificer

auwun nowéta nartâuewéwhékachad [arwebéfitted, placed, and joyned them ne] wuftaúwus, wezfhataúwus, quah wonappe-
together; númnafh-hanth; rio, naumókq' kefukq' $\begin{array}{r}\text { quah } \\ \text { earth framed }\end{array}$ okke rio wékekekòzzous quah rawwe wame

keizhittifhannak, pafuk wertáuwe unkataggan and all things to their proper quah wame aiákquiiks wajekeiztámmakus ou-

warchanith, newaûwun hom matta webe pakclude that there is a moft wife maker kaddawâmen neh oúffewe wawántam nártauof the world, and all things intàntak wutche mittâukuk, quah wame aiakqui-
in the world, and this can be iks mittâukuk terre, quah youh hom mutche no other but the true God matta únkatak webe wah wérramat Mando Jehovah. But many
Ob: Wepe oùfawadj mátcherewunganfh pa-
are done kodje ahrèmuks mittáukuk terrè quah utteamopein mens hearts

tànguanân rènawauk mittahhâuk terre moh mutis the author or the cause che Fehovah nègonquàjh/hâuanu/h ux waje yous of those evills? matcherewunganfh wutchio? 


\section{[19]}

No for

is of himfelf

An: Matta wutche Jehovah nàgamo utfe perfectly good, fônke werrégo, mukko milkiffowunk wutche acting be of yet this rémuk mutche Jehovah wutchío, narra niànchabufe of that power to act tauwunk winfully
is youh milkègowunk rêan màtcherénag attàmo wutche nagamauwhoggauwâuwo. Jehovah keizheàuwus Angelok quah rènauwok wêeche mótantammewunk of acting which was not vicious wutche ahrèmuk; youh matta mumatcherèyet it might by its own power muk, narra youh hom fpe nagamo milkiffewunk pâdah chawgun nowèta matcherèmuk it was from the abufe of their moh wutche aianchtaúwunk wutche nagamaùfree will that fallen angels, wo mótantammoùngano neh teâkfèjek angelok now devills and and eo mamatchhuadjieck quah. Adam quah Eve and in them all mankind finquah rame nejek wame renawauk matcherened.

wuthannak.

Though be not the caufe of finn, Ob: Mukko Fehovah mattà waje macherewunk yet are there not two active beginnings, the one narra weep matta nefuog negonquafhadjek, pafuk
good; werrego quah wajaiunk wame werregunf ; 


\section{[20]}

the other evill, and the author and cause katak matchere quah negonquajhak quah waje [wutchiamuk] mátcherewunk?

That cannot be, for

if there were two

An: Matta erána, wutche hom nèfuog fuch contrary acting beginning they would rífoak pómparrerèjek negòuquagidjék yèiache always be fightings one againft another

hom aióutoak deftruction would follow.

\section{nèoutche}

aifkomhít-

tawunk 'om nôfkoffômo.

2. Matta chawgun ro rio matchitto is of himfelf $_{\text {good }}^{[\text {mat- }}$ chère] arra God nagamo utfe werrègit wutche matcherewunk mutche tupacha chawgun quefect $\underset{\text { not }}{\text { rauhikkowunk, }}$ be but in matta mutche webe rame chawgun nowêta exiftent, and to exirt pummayamuk, quah pummayne mutche fome good.

chawgun warrêguk.

The true

3. Wah wèrremat God uttâhhe wame ftrength

milkiffewunk

the gods and quah of the heathen thajofhawùnganth ; mandoak èanfketàmbough hókkiffenègoak and poor. He fills heaven quah matchègoak. Ewo weremâttawn kefukq and earth, and is everywhere in all the world. quah okke, quah wampfik wame mittauk. 


\section{[2I ]}

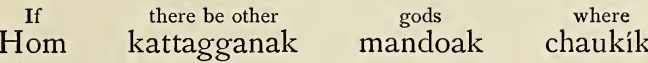
are they? appòak ?

Seeing
Qu. Mukko Fehovah keiftânas kejukq, quah
earth, and all things okke, quah wame aiakquiiks rame neifh eo wunnow leave them and nomore look after nagottámmin nêjek, quah matta nôufe anambatthem as a carpenter doth leave
támmóan nairrène arra nartauôukachad nokódtuk an house he hath built? wejo keiftánkq'?

No, for An: Matta, wutche nattauôukachad matta not after the houfe he hath built, not nouffe ámbatammôan wejo keiztaukq', matta for himfelf, otherwife, if he made it for himfelf, nagum wutche, perrére, keiftáfhan nagum wutcontinually he doth look after it. So che yeíache nouffe aûwambattámmen. Rio God made all things not for an keiztaûwas wame aiákquiiks matta wutche katother but for himfelf, and therefore doth tak, webe nágamo wutche, quah negaùche konpreferve them and govern them for the ends kedjheânts, quah uttoûkretâuwah nañe waje wherefore he made them and to which he appointed then keztànguthanfh, quah waje pakkàdaws nañe, and according to $\mathrm{y}^{\circ}$ feveral natures hath given quah nouffe perrerambanúnganth merâuwus them; Some by Reafon, as men nanne; Polhfhe fpe penaûauwunk, arra rénaothers by their natural inftinct wauk; únkattàgganak noufe nagamaûwo ar- 


\section{[22]}

as Senfitive creatures;

rumbauhit arra wâuwayómuks keízheoufhan- others by their natural nak; ùnkatàgganak fpe nejek arrumbaûwous propertyes as the fire, afcends áchachabehittawúnganih arra ront' ematháand water defcends.

mo, quah nip'p' wámtchawànha.

How do
Q. To gouje koràmen neh Fehovah wo- -
vidence kòmhuwàwunk tô̂kretauwah wame mittâuk?
By
the motion
of

$A n$. I. Spe pómpemomòwunk wutche things againf their proper aíakquiiks taûtapókkacha nejek nàgamâuwo nature for the good of the uniarrumbaûit wutche werrégowunk wame weèverfe as we fee fire winnakõmuk wutchío; nenar naûménan yout will defcend and water, afcend bitch wômpfháno, quah nip' wamitchche- wafhiha perrewerampâuómous affànum faûatinefs for the good of the uniaioówunk wutche werrégowunk wame weeverfe. wínnakommuk wutchio.

By the natural care which

2. Spe arrumbaũwe nèmarrewúngan teounot only men indued $\mathrm{w}^{\text {t[ }[\mathrm{b}]}$ underftanding, but alfo matta webe renauwank wawantàjèk, qùut nanak oppifhim quah oppifhfhauk tooùick querauhikkóank penauwauwunk uttâheàuk wutche 


\section{[23]}

their young: which being a part

neíek wunnaiànawauk; youh muche chaippaio

of goodnefs

muft

be

acknowledged

werrégowunk muche pahke milhuommiñau-

wo [wérremuttamaûwo] Jehovah or wutchio òuffewaié rakque wame ewo keizhittifhanin the world: and the rather becaufe he is

nak mittaûkuk terre: quah aufe wutche wamprefent every where and knowes all pfin wame mittaukuk quah wâutawn wame aìkquiiks, quah hom nukkomme pakkadaway them to the ends wherefore he made them.

nanne waje kezhéants.

3. Jehovah toukrêtauwah chezous, nénepómiha quah arraxfuk quah niguilquats kefakuk

wutcheò̀tambazfowúngan

on earth, principally of man.

nketohke, móucheke wutche ren.

$$
\text { Becaufe Common-weales }
$$

of the creatures
keizhittifhannak

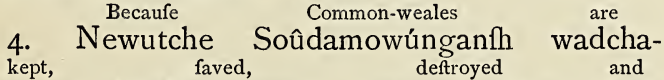

nazzous, konkeóitazzous, panquatazzous quah changed

azzawunuamanoufh fpe warrantammowunk

of God.

wutche Mando Iehovah.

Becaufe all men ingreat diff-

5. Wutche wâme renou fhaíous únquoculties $\begin{gathered}\text { diftreffes } \\ \text { and }\end{gathered}$ 
exigents naturally do cry to God fiagutufh ùtterumbauwe manóuwok Iehovah for help which teacheth wutche airenamaûwetœowunk youh kòkkøodaus that the knowledge of Gods mungquêakq' neh wauhtaùwunk Iehovah providence towards all perfons

wokomhuwâwunk rakque wame fketàmboúgh and things upon the earth is implanted quah aíkquíiks lket-ókle rame ókkekekózzo [pòkkoddekekozzo] rame rambauwous mittafh wutche wame ránawauk.

$$
\text { How do you prove that all fingular }
$$

Qu. To goojt korámen neh wame nanfaious things are governed by Gods aiàkquiiks toukretauâuk fpe Fehóvah wo- Providence? kamhuwázeunk?

Becaufe fingular things are or$A n$. Wutche nanfaióus aíakquiiks pakkad-
and
directed wandámmenufh quah kóodemantamménufh to thofe ends whereto God made them. waje yous keiztángus Jehovah.

$$
\text { Becaufe God is prefent }
$$

in the whole

2. Wutche Jehovah wampfin wame weewinnakómmuk, quah ewo wawantámmówunk and ftrength are Infinite.

quah milkégowunk wame-arroukamóôak,
Becaufe
generals
do fubfift

3. Waje, wame fchifh útteamopétánguanau rame nanfáiamuks: quah newutche hom 


\section{[25]}

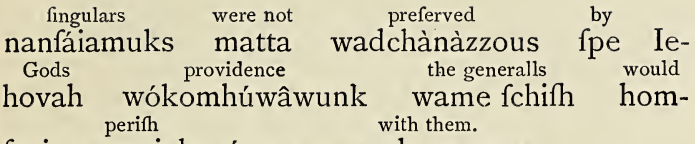
faviouwe aiakquí yous weeche nanne.

$\mathrm{Ob}$ : Hom rakq'; ten wutche artak neh matSin doth fo abound in the world? cherèzeunk rio ouffewàrrat mittaukuk terre?
Even
the finns
that
abound

$A n$ : Nux matcherèwunganfh yous ouffewarin the world do manifert

that

retufh mittaukuk terré mous kinnamaúok neh

Gods

providence

doth govern

all

Iehovah wókomhuwáwunk toukrêtauwah wathings on earth. Becaufe thereby

me aìakquíks fkejeókkeak. Newutche, neh weethe effects

of finne

are

che úttereúnganfh mácherewúnganóas womkept under limmited reftrained kâuoúwok, fachwhúngaukaùauk kopehommeand hindered leaft they fhould nufh quah úttamkekáiroufh chaugo hom kokproceed fo farr as otherwife koodrefhahúwauk rio ríkkaque arra kaddawe they would

to the overthrow of werrantámmok pauquatauúnganak re wutche Common-weales and that one man foûda mauwúngafh quah aia matta pafuk hom fhould not live by another. pómpemantàmmôan weeche unkataggan.

$$
\text { Becaufe over-ruleth }
$$

2. Wutche Iehovah wunna toukrêtaũwah the effects of mans úttereúnganfh renou finns matcherèwúnganóas, 


\section{$[26]$}

which

he

permitteth

to

(teous tapatchch' mattaoúffambamáuôan) augood ends either to Punifh

one werrèganak
wicked-man nukqûudde tatággaman $\underset{\text { another }}{\text { pafukq }}$ or to mámattambauit weeche kattággan, ux tacorrect his own people when tàggaman ewo nagamo wufketambamh wâuthey wander from his righteous

wannawàhittit wutche wuffunkkówbâuous pakRules, or to try the

kadtawàuwúnganfh, ux kutchtâuwun werfaith patience and con-

ramattámmewúnk tokâuafounk quah yéiaftancy of believers eminent in chewunk warremattajek maffambàujek werritgrace.

tepantámmewúnganak terre.

$$
\text { Becaufe though }
$$

Becaufe though Newutche mukko God túpacha matta óusmitts wicked men to

fambamauóan mámattambâureatch kokkoodprofper in this world for a

rewéaweghìttít youh mittâukuk terre wutche time; at laft when they dy

quompàio ; narra uttajiauche nannúppohittit, God's punishing will, fhall Jehovah tàtachâuwe wérrantàmmowũk bitch be done upon them who would not keiztàzzo lkeje nejek, auwannak mat werrantàmmóauau rêan Iehovah
will pókkotchim-mâu weróytammewunk quut mattawéwezàmmóguk thereunto.

ewówunk re. 


\section{[27]}

Becaufe
4. Wutche rio
to look wauk útteambáttámmen tfaió wáffimiddebefore it come after

wunk wutche afkam poámo nau uttákgutche this

youh pòmpemantàmmewunk youh terre God will render to all men after their bitch meràh wame rennawauk nouffe nagaworks in this world.

máuwo wuttarkáffoungãfh youh mittaukuk terre. How do you prove that the foules

Qu. To gôje koràmen neh mittachónkawawk of men live when their rènnawauk pomphmmantàmmok hoggauwo pok-
bodyes be dead, and that joul kothche nuppeat', quah neh wittachonkp' quah body shall be joyned together to appear before

nihok bitch náppinnâuauk moufkeane arquabit God in that fudgment?

yow wà $\int$ imidde wunganak terre?

By the power of the natural confcience

An: Spe milkegówunk rambáuwe mittachoak of all men comforting them wutchio wame rénnawauk mámmachewàhuwã when they do well, accufing Judgnejek wéreréhittit, quah môuniffhàffowan wasing and tormenting them when they fèmoán, quah kéiappenáffowan nejek matchedo evill, efpecially near their death, which réhittit, chówonche kifhke núppoungano, teau thewes that they expect a Judgkokkôadumchàmo neh áfkwhontammok wasment to come.

femiddewunk yow bitch peámo. 


$$
\text { [28] }
$$

2. Spe rambaûwe chówoutàmmewunk of immortalitie which wutche michéme pompemantámmewunk, teou is in all men. útteamopétánguanau wame rènnawauk.

By the natural motions and

3. Spe rambâuwe róytámmeúnganfh quah expectations that Indians afkwhóntámmewúnganfh, yow Eanfketàmhave living boûgh uttâhhénau wutche pómpamantàmmein another country to the fouthward after wunk perôu kon faúanáiôuk pòkkache they have lived in this: we pómantammowúfhànnak yowh terre: nâumefee trees in winter loofe their beauty nan p'tuks pabôuks antâumous werrégowunk and in the fpring live again. quah fequoks kejámous rambe.
Qu. Ten God toûk kretâffo ren?
$A n$. Spe mâugun quah negonne wûfkwhon$\underset{\text { by ordering }}{\operatorname{tammen}}$ pakkàdtawâuwank re nagum, quah pakkadawan neh arra réunawauk àttumreceive that law they minúmmok youh pakkadtawâuwunk micheme thall live for ever in Gods love; bitch pompemantammok Iehovah wómarretoûnganak terre; $\mathrm{ux}$ arra apôkeitamhit youh

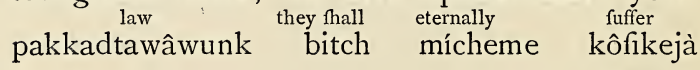
pen 
mifery, its meet that a reafonable creature made penáuwauk tabe ne pénauáuwe keizhittis reftauwun noufe wuttézzowunk wutche God mutche be fo governed in way to everlaftrio toúkretázzo maouk terre michéme kejaning life.

wunganak re.

Qu. Chawgun pákkadtawáuwunk moh God prefcribe to men? and how negónne wufkwhómmenas renouk? quah tokè nedid he prefcribe it to him?

gónne wufkwhómmenas ewounk re?

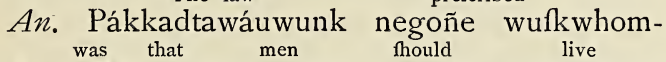

muk moh ne rénawauk mouche pómpemanafter Gods revealed will

tamminau nouffe Jehovah moûfkíñamuk wérranrevealed to men támmowunk: God moufkinnamáuwus renon that his will of old partyouh wérrantámmewunk nah rôwat, chánchely inwardly, by writing his paièwe, ramaie, fpe wufkwhontammen ewo pakkadtaúwunk rame ren uttâhhok' terre; partly outwardly by declaring chànchepàièwe pokôtchkaíe fpe ránjemokântammen chawgun ewo werràntammen [pókkotchaimóa] ne ren pauhke uttein, quah
avoyd, wúnnagattúmmen, milketâwun youh pakkadta- 


\section{$[30]$}

to man by promises and to man
wáuwuk renouk fpe nóremittaffounganfh quah
threatnings wezzamwauwúnganfh quah mouchewopreân man to obedience by a folemn ren wanweztàmmawúnganak re fpe quofetamcovenant. min wérrawâwunk.
Why did.
reveale his
mind

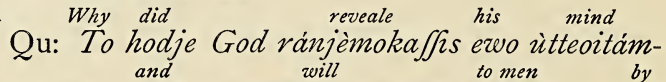
such like outzoard

meanes

arrizous pòkotchekaious athrewatchchàmuks
seeing Jeeing he governs
nàrraga toükrétâuwah unkattágganok keizhittifhà-
after another manner. nak nouje pervere. $A n$. Wutche ren youh pòmpemantammewún- underfands by his fenfes;

ganak terre waughtawn fpe wauwaiowunganfh as by feeing and hearing therefore arra fpe naumuk quah petámmuk, negowaje God útteranjemen ewo útteoitammewunk remen outwardly partly by douk re pékotchíequiouk, chanchepaìewe fpe fpeaking to his eares by an kéketokantammin ewo taúakok re fpe ru-
audible wawunk hompetammauwo, ne ren hom petammin $\begin{gathered}\text { and } \\ \text { caufeing }\end{gathered}$ waughtaun chanchepaiewe fpe wufkwkofhitten ewo werrantammowunk wufkwhe 


\section{[3I $]$}

$\begin{array}{ccccc}\text { a book } & \text { that man may fee, } & \text { malk- } \\ \text { whegannak-terre, ne ren hom naumen, òk- }\end{array}$ read and undertand what

kekkenâumen quah waughtaun chawgun God willeth that he know and do werrantammo ne ewo wâutawn quah uttèin that he may be bleffed.

ne hom wâuwerrehèa [chadchemo].

Q. Mas woh the will made known to man at all times moufkeuázzo renunk re aiache nah quompaious by being written in a book?

Spe wufkwhazzen wufkwhêganak terre?
It was alwayes
neceffary
that the $A n$. Yeiàche moh queràuhikkomuk ne wérwill of fhould be made known

rantammowank God muche wauhtauhcwànaz to man by a word, for

renunk re fpe kékatokàuwunk, wutche God would never

mutche matta wúfferawâuh-hean [wérzfhahèany worhip or fervice an] chawgun nowéta nokómmounk ux roútasfrom man but what was fewunk renouk wutche, webe chawgun moh according to his word, which word noufe ewo kèketokaúwunk, teou keketokaúis the only Rule of the wunk mutche webe Kekráffowunk wutche Obedience

wauweztámmewunk of men towards towards God but this chord
rakque Jehovah. Webe youh keketokaúwutche rennauwauk was not written at all times for wunk matta wulkwhommómuk yeiache, waje, wut 


\section{$[32]$}

from to revealed

wutche Adam re Mofes, God móulkinnaffoas his will vy vifions

ewo wérrantammewunk fpe kemenâumhewadreames, and

wúnganfh, úttenoquomoúnganfh, quah manOracles

to few dówaioufáttabbawâuúnganfh re akkôffiffoak, and fpread it from them to quah fòenúmmis youh wutche nejek rimmany the father teaching his fonn, fharoauk re, oufhi koodumauwun uttaíum, and one making known to and

quah pafuk waughtâuhùwan quah kooteaching another the will damchâuwâuhhuwan kattaggan wèrrantamof when the Church mewunk wutche God tabanah màuwewhékowas thut up in few muk moh bóphammine rame akkoffiffoak families.

Wauweketajek.

Why was

Qu. To hodje uttuwàuwunk God wutche niafterwards written in a book?

tajiâuche wufkwhòmmuk wufwhèganak terre?

An. Tâbanah maúwewhékomunk moh koenlarged

and began

to fpread it

kôodrefhanchh' quah noujèwus mèrrammefelf into a greater compafs and alfo errours moûjereaufe unkòuwea, quah nanak pèrrewoyin Religion

tammeúnganfh wèrrerôutaffeewúnganak terre increafed and Gods kòkoodrefhamewúdih' quah Jehovah oufketam 


\section{[33]}

people

converfed

with

Idol-

tàmbamh wejíoumekonafhannak weeche pèrreaters they were more fubject

aiàrrôtàuffejek nejek aufe núkkommehèawusto be milled then it was hánnak pérreràuweehittewúnganak re nène moh neceffary that Gods word fhould queràuhikkomuk ne Jehovah uttuwâwunk pauhbe written in a book.

ke wufkwhazzen wufkwhègannak terre.
I To prevent
forgetfullnefs.

I Affannaman wúnnoytàmmewunk.

\section{To avoid} errours.

2. Nókottúmmen pèrrewoitámmewúnganfh and preferve the Trueth of quah pòquaúttawne werremâuwunk wutche God wutche matcherèahittawunk [àiautekómboûjek] $\begin{gathered}\text { in all } \\ \text { but one }\end{gathered}$ ant antewúnganak
true terre, $\begin{gathered}\text { there being } \\ \text { and }\end{gathered}$ righteous pafuk erráno quah fònkkumbâmuk kèkraffowhereby to judge the trueth wunk youh fpe wàffetúmmen werremâuwunk
3 Nilketawn wame rénnawauk youh ischauúnganak terre ne Jefus Chrift (rame auwanwe believe is that Saviour

he nôrremattàmmokq') youh artak kekejábùad,
in whom all $\underset{\text { and }}{\text { auwhe terre wame króudamâuwetoúnganfh }}$ of the old quah negonnióus ahruwâmuks wutche nekonne Teftament were fulfilled which is nôkottammâueten moh immartâuauk youh C wauh 


\section{[34]}

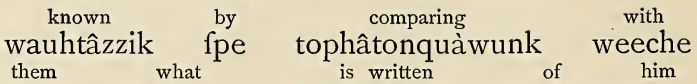
yous chawgúnne wufkwházzit wutche ewo, in the new Teftament and fkaio nòkothommâuwetoúnganak terre quah therefore that there is not another name elfe given nègowaje ne matta wunk wèzzawunk merritunder heaven whereby wee may tenaz ramuk kefukq', teôufpe neàuwun hom be faved. kedjhitchamen.

What is that book wherein these Qu. Chaw gun youh wufkwheâk teounk terre yous things are written? aiakquiiks wufkwhazzous?

$$
\text { It is that book called }
$$

$A n$. Youh mutche wufkwheak affwedámon Gods Book Gods word the Bible, Jehovah wufkwheak, Jehovah attuwauwunk, Jehovah werramauwunk, youh werteineth ramafhfhatawn [miáfhfhatawn] pákkadtawaûwunk, wufkwázzit fpe Mofes, quah negnniíjekahrûajek. Quah fke nókothommâuwetounk teowhich wee have a full and unk terre neauwun noutahhénan rematta quah manifeft difcovery of the myftery fonke móufkinnamawúnk wutche peaio kemèwunk wutche Jefus Chrift.

How do you prove that this Book con-

$\mathrm{Qu}$. Togooje koramen ne youh wufkwheak werremafh 


\section{[35]}

teineth

the word of

ma/h/hatawn uttuwâuwnk wutche God?

Becaufe

it conteineth

a wifedom

A. Newutche, máiáfhfhatawn wawantámfarr above all that can bee mowunk werréna aufe wame youh hom mìffenhad Princes,

namâuwo fpe Sáchemâuauk, [kóttafoodamauor the moft learned and wife ok] ux oúffewe kókkoodamâuiek quah wawánmin of this world. tejek wutche youh mittauk.

$$
\text { It makes wife }
$$

Gods

Elect

2. Wawàntamhuwámo Jehovah mamúkkinnamáffeiek michème kéiauúnkanak re.
Becaufe
the Prophesies
conteined

3. Waje negónne ruwámuks cópehammâuous Jehovah wufkwhèakgannak terre fonke, and punctually fulfilled.

quah kitche kèztaunaûauufhanfh. hath from time to time

4. God pompio wutche quompiewunganak re kóukejappeunachàwus poqâuwe màttekàrreof his Book, and kuts nágamo wufkwhéakganfh wutche, quah adverfaries of thofe who have

máttekárrekuts wutche youhjek auwúñum wérprofeffed and practifed

ramatahéwưhánnak quah utténauwưhánnak the Religion and worhip of peántammewunk quah roûtáffawunk wutche taught therein.

God ókkekôodamàmuk youh terre.

$\mathrm{C}_{2}$ 


\section{[36]}

Becaufe all men in all the

5. Newutche, wame rénnawauk wame mitworld are required to worhip accordtaúkuk terre pókodjemóauk routaffen God noufe ing to this his word.

The greateft princes of youh uttawâwwunk. Kóttafoodamaúwauk wutthis world have their limits. che youh mittauke úttahèauk nejek fachwhúnhath none.

ganfh. God matta outahe chawganfh.

God's word was given long

Ob: Fehovah ìttuwâzennk méritten rôuagoe, How then doth it concern those who now wat. Tógôoje pókkodjemoàmo [wajaït] youjek eo pompemantámmok kefeque?

\section{God's word}

Ans. Jehovah ùttuwâwunk môufkefhàddawn his eternal and unchangeable

nágamo micheme quah matta áffawúnnamòmuk Will, concerning all wérrantammowunk, wutche wame aiákquiiks
neceffary $\underset{\text { done by all }}{\text { querauhikkomuks }}$ who berramattaûwun quah úttenâuwun fpe wame auwúnnum kíttechowontamok kejáhéan wame ántfeúnganak terre; quah newutche moh wúlkhommanaûwo neaûwun as well for thore cor who Lived
wutche nenar wutche youhjek pompomantamlong agoe, mowufhannak rouwat eo poôpe. Rom. I 5 all 4 ; I. Cor. IO. II, wame wunnejánnak wutche 


\section{[37]}

fame

firft

parents

and

nenar negonnéjek oûfhewâwok Adam quah Eve, God keiztaunkq' wutche pàfakun nepuk wa- all nations of men of the me arkêiz rènawauk wutche, Adam wutche Earth and of his rib, and okkèik quah Eve wutche ewo pechaûgun quah fo one man begat another, and rio pàffogun ren rikhèaus katággun, quah

ne ren katak, quah ne ren katak; quah ahàntfe generation begat another, fo all men are as rikheoûfhannak, rio wame rénnauwauk arra branches of the Root pápechewékeiek wutche Adam wutcháppuk wame rénnauwauk arrámbaúauk: wame ahárfoin theire bodies, theire heads;

eares,

ak hogkâuwunk kéounúnguanak; wuttaûauks, eyes, mouth and tongue.

fkefuks, wuttoân, quah méran terre.

Gods word was given to

$\mathrm{Ob}$ : Fehovah wufkwheâk moh mérvitonaz ìnother nations how then doth it concern the Inkátággohauk re tennéne pakkódje-moamo éanfkedians.

tàmbough.

An: Jehovah uttawâwunk moh negonne

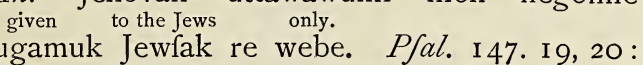
máugamuk Jewfak re webe. Pfal. I 47. I9, 20 : Rom: 3: 2. afkam paíaant Jefus Chrift God moh fuffered all nations to walk in their own kònkokáñaio wame arkeis pummêan [matchêan]

$\mathrm{C}_{3}$ (nejek paaijawunga- 


\section{[ $3^{8}$ ]}

wayes but when came nak terre, Acts, I 4: I 6. kíttaman Jefus Chrift paiin mans nature hee fent ant' rénambauúnganak terre ewo moh negòntua his word to all Nations of the World. uttuwãwunk re wame arkêis wutche muttauk. Mat. 28. 19. Acts, 17. 30. noufe negònne auwaprophecies of and of muks wutche Iefus Chrift. Efa. $49: 6$. quah wutche the Gentiles which his word they Gentilloãg. E/a. 65. I. Ne uttuwãwunk nejek miffènnamanau pothe negonne polhe utta, auche. If the Indians receive Gods

Ob. Hom éanjketâmbough miffimnamanau IehoWord will it not wah wufkwheâk [uttuwãwunk] matta youh bitch mammoânhokkréztawâuwunk quah pâuafjoinganjh wutche Sachemãuauk, quah motántámmewunk èanfketámbough?

No, in noe wife, yea this An. Moh wutche matta erano. Nux youh would quickly increafe hol the honour and Riches of the : achems, quah paûafowunk Sachemauauk, Pro. 8 : I 5 ; to 20: Cap: 22: 4. Spe wòmarromónk quah wèzzarrakounk wutche God paûafounk kokkrez- 
honour, and life, and this kréztawâuwunk, quah kejâuunk, quah youh will inlarge the liberty of the bitch arrôuha mòtantámmewúnganth eànfkeIndians by freeing from támbough, fpe motántámhùwan nejek wutche the bondage of Sin and mifneghittewunk mátcheréwunk quah mamatthan. chhúâdjek wutchío.

$\mathrm{N}_{\text {Ezze enhitta }}^{\text {The reond }}$

part onewing them by the Scripturesio okkekôodemúnganauans fpe wufkwheganfh wutche God màndodivine truths neceffarie waíous wérramauwúnganfh querâubíkkomuks to eternal falvation.

re michéme kejàhíttewunk.

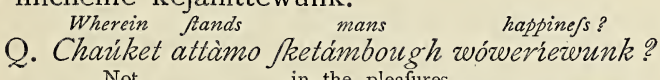
Not in the pleafures

An. Matta pómpawoytàmmowûnganak terre, nor in the treafures of this matta thájoffhewúnganak terre wutche youh world. mittâuk.

Qu. To hóhje?

Becaufe our life is fhort wee

An. Wajé kokkejauúngan taíoquíah, neaûwun hom webe n'tahênan yous nàmach'. Fam. 4: I 4: Luk: I 2. I 9. Pfal: 49. I I : I 2.
things
fatiffie

2 Yous aiakquíiks matta hom kàttabrawâhíkko-

$\mathrm{C}_{4}$

nàn- 


\section{[40]}

now while wee live nor will nànanfh eo fakkepómpomàntammokq', matta they accompany us when we dy.

kowéjauúngan nuppôan. [ahquefkétámbaûmitch]

$$
\text { Wherein then ftands mans happiness? }
$$

Qu. Ten artah néne miffin wówerriewunk?

Mans happinefs confifts in the

An. Renna wówerríewunk artah wadchañamfruition of God his free âuúnganak terre wutche Iehovah narrâuwe wóLove by the chief defireable

marretewunk fpe Iefus Chrift, árchewontàmmuk
good
that any
any can feek for

warréguk têou howan nowêta hom natchkok or find.

ux umfkómmen.

Qu. Thy forje?

An. Waje youh wómarretounk attah wutche everlafting and to everlafting, it ceafeth michéme quah mechémewúnganak re, matta eaknot, quino. Fer: 3 I : 3 .

2 Wuña narraûwe Hos. I 4. 4. 3 Wame wómarits the greatert,

retoúnganfh arche mêfi. Foh. 3: I6. 4. Artchetàfying.

brawahíkkomuk. $P \int_{\text {Wherein }}$ al. 63. 3 . Qu. Ten terre Fehovah arche wâughhewâwun
to men?

Sketàmbough re?

An. Uttúwawúnganak terre teou moûlke fhad 


\section{[4I ]}

men what they ought to avoyd fhaddawn rénnâwauk; chawgun pâhke petahbelieve, and doe that quenah, wârramattâmmanah, quah útteeínah ne they may pleafe live nejek hom wôfferawahênah God pómantầmto him yea live for ever minah ewounk re nux pómpamantâminah michewith him.

me weêche ewo. Rom. I0. 8, 9, I I. Tit. 2. I 2. Who is

Qu. Howan God?

An. God Rafhfhâuwunk micheme wameknowing, all-feeing, moft mercifull, waughhèan, wame naûmen arwe-kíttamanchâfko moft righteous of himfelfe, and arwe funkkúmbaugh wutchio nagum hogga, quah himfelves

(Foh. 4. 24: Pfa, 90. 2: 2 Chro. 6. 30. wutche nagum hogga. Ex. 34. 6, 7. Ex. 3. I4.

\section{Q. Chófjoak Mándoak?}

There is but one very

true

in

$A n$. Webe pafuk waugh wèrramat God rame three perfons three in one, the Father, the Son, fwe perfonôag fwenâpffha pâfuk, oưh, wôamón, and the Holy Ghoft.

quah peaió Rafhaûonk. Mat. 28. I9.

as in man there be his will, underfanding, nenar rame ren wòrrantámmewunk waughtaûand memorie, thofe three, wunk quah mèmequantammewunk yows fwe, yet but one man: So in the God-head narra webe pafuk ren: Rio mandoôwúnganak there are three perfons, yet but one terre, fwe perfonôag, narra webe pafuk God. 


\section{[42]}

this is myftery which Youh àrwejanúnquat peaió keonèwunk, teou will reveal more fully to his people Iehovah bitch kôodremóufkenàffo re oúfketámboth here and in heaven bamh takque youh, quah rame aûffequámuk hereafter. etántèrre.

What hath the true God done -Qu. Chawgun waugh werràmat Mandoh kekezfor thee?

tàngus wutche ke?

$$
\text { hath made me, he doth keep me, }
$$

An. God nekezhúiggus, ewo nènowadchànand he can fave me.

nakq' quah ewo hom nénokedi huikq'. $\quad P \int a$. I I 9.

73. Pfal. I2 I. 4, to 9. Efay. 63. I.

Qu. Ten God kéteoufhikquenas?

Qu. In my firt parents An. Rame negónne neghikqueoúfhánnak $\underset{\text { and }}{\text { pè- }}$ and rambaûhuiggus, quah fonkkómboûhuiggus quah like himfelf in knowledge.

rizzo nagum hogga waûhtauwúnganak terre.

Gen. I : 26, 27. Ecl. 7. 29.

$$
\text { Are you then born holy and }
$$

Qu. Kinfpe nègamus pêràmbaugh quah Sônkrighteous.

kómbough.

$$
\text { No, my firft father finned }
$$

An. Matta nègónne noưha màtcheréoûfhan and I in him.

quah nentéramopetángun. Es. 43.27. Ro.5. I9. 


\section{[43]}

made

the firft man

as

God wufhéawus Adam negónne ren tupacha the root of all mankind and wutchòppuk wutche wame rénnauwáuk quah gave and in him all men meáwus Adam, quah ewòunk terre wame rẽnou all good things what wame waugh worrégix aiakquiiks chawgun Adam miffínnamanis wafke keizhéant God he received it not for himfelf alone with mattax nagum webe wutche miffinnamónis, wehim all men

che nagum fketambough mutche wame miffinnamauauwufhannak: quah chawgun tantâuanufh hee loft not for himfelf alone all antâuamufh matta nagum wutche webe, wame men loft it in him tàntauanâuwulh rénnauwauk ewounk terre what did as if all men chawgun Adam arretch netátuppe wame rènnawauk wúttenâuaus; ewo màtcheréwus newutall finned.

che wame màtcherèoufhànnak.

Queft. Keko nêgamus mámatcherêt?

I was conceived in fin,

Anfw. Spe wámpaquàanas màmattàmbauwúnand born in iniquity

ganak terre, quah fpe négamus màtcherewùnganak terre, Pfal. 5I. 5, quah rio fpe nêen tenature am as loathrámbâuwunk netátup matchenúnquofo matche- 
fome creature and in myfelf by múnguofo keizhêak quah nehoggok wutche matcherèwunk chifhánttammuk re Jehovah.

What is your birth-finn?

An. Mátcheréwunk wutche Adam nummíato mee and a corrupt nature

namâuhikquemuk, quah mátcherambauwunk dwelling in mee.

uttéamopetángun. Ro: 5. I 2, I 3, I 4. Eph: 2, I 2.

What is Adam's matcherèzounk kummia-
Q. Chawgun Adam mouted
to you? namâuhikquemuk?

The eating

of the forbidden tree. Gen. 3. II.

Ans. Meêtfin quótetemúggus p'tuk wutchío. what is your corrupt nature?

Q. Chawgun komátcherambâuwunk?

My corrupt nature is empty of

An. Nomátcherambâuwunk fauaiôo wutche grace

wérrittapautámmowunk, upffquâuwémo mátunto finn, onely unto finn, and cherénag re webe mâtcherewunganak re, quah that continually.

ne yeíache. $R o: 7.7, \&$ I 8, verfe. Gen: 6. 5 . not a creature upon earth, hath fo an infected nature all all men huwamuk rambaûwunk arra wame rennawauk have.

uttahéauk.

What is
Q. Chawn? 


\section{[45]}

Sin is

a breach

of

A. Matcherèwunk pôakquínnamounk wut Gods Commandements.

che Jehovah pakkadtawâuauwúnganfh, I. Foh. 3. 4 .

How many Commandements are there?
Q. ChofShinoh Attak pákkadtawâuauwringanfh?

A. Paiâguotufh, Deut: 4. I 3 .

What is the firft 4.13 Commandement?

Q. Chawgun negónfhik Pakkadtawauwunk?

Thou fhalt have no other

An. Matta bitch komandómo unkatagganok gods but mee.

mandoak webe Ne. Exod. 20. 3.

What is the meaning of this Commandement?

Q. Tah ruámo youh Pakkadtawâumunk.

That wee hould worhip

$A n$. Ne neâuwun pâhke ketérrôutauwaûmen the only true

webe wérramat God. Mat. 4. Io.

is the onely true are

Jehovah webe waugh wérramat God, matta únkno other gods the gods of the atágganok mándóaog, mándóaog wutche okkeinfidells are Devills ajwauhtammejek mamatchhuwadjek quah renayers.

nou-nanfchadjek. What is the fecond Commandement?

An. Charugun neztâufhik pakkadtamâuwunk?

A. Matta bitch koufhèa mis-feânwufkwhôsimage unto thee or the likenefs fen tûppacha mandôuh keunk re, ux neárrak of any thing which is in heaven above wutche chawgun nowèta, teou kèfukkuk fkeje 


\section{[46]}

or in earth beneath,

or in $y^{0}$ water under the terre, ux okke ramùk terre: ux nippe ramùk okke earth. Thou thalt not bow down thyfelf terre. Matta kekúpfquâwưh wamaíouk kehok to them, thou fhalt not ferve them re nejek, matta ke bitch tàrroukáffomah nejek for I God thy am a jealous wutche ne Jehovah ke God mouffit-chamo [aharrachàmitch] God, aharroûtant matcheréwunk of the Fathers upon their children koufhwàwok wutchio fkeje wónnajánnawauk to the third and fourth generation, [múkkràauk] re fwot quah youwot antfèwunk of them that hate me and wutche nejek chìhfharamoquéanak ne; quah rhewing mercy unto thoufands of kittematchèrachan re màmattinùnguefóak wutthem that love me and keep che nejek wòmarrequeanak ne quah wadchânmy Commandements.

jek ne-Pakkadtawauàuúnganfh. Exod. 20 4, 5 .

Foh. 4. 24. Lev. 25. I. Ezek. I6. I7.

What is the meaning of this Commandement?

Q. Tah ruwàmo youh Pakkadtawanaumunk?
That
wee
hould
worfhip

$A n$. Ne neauwun pahke nókkommoukaûwun The true with True

wauhwerrámat God weeche wérramamuk nòkworhip, fuch as hath ordained kommowunk, nenar God pàkkadafówamòas [pakkaddawanas] matta nenar renou arroytamhit. Fohn. 4. 24. Deut. I 2. 32. Mat. I 5.9

Queft. 


\section{[47]}

Qu. Chawgun nafhwe Pahkadtawâuwunk?

What is the Third Commandement?

Thou fhalt not take in vaine

An. Matta ke bitch mifhómmôan tah-noôche the name of thy God, for wézzawunk Jehovah ko mandouh: wutche Jehovah matta bitch wuffomòôan parrewauhhuwa that taketh his name ouwannouwéta mammo nagamo wézzewunk in vaine. tah-noôche.

What meanes here the Name of thy? $\mathrm{Qu}$. Tah ruwámo youh wezzewūk wutche ke God? Himfelf, and the good

$A n$. God nagum, quah waughwauwerrégix things of whereby is known aíakquiiks wutche God, teoufpe God wauhhéa as a man is known by his name nétatup ren waughéa fpe nagomo wézzewunk as his Attributes worhip nenar úttarwejanúnguefoúnganfh nokkómmoWord and Works wunk, uttawâuwunk quah wúttarkaffowunganfh (Deut. 28. 58. Ex. 30. 19. with 34. 6. I King. 9. 3. Pfal. 138. 2. Fob. 1. 2 1. What meanes that palt not

$\mathrm{Qu}$. Chazegun ruwãmo youh matta bitch komtake his name in vaine? ammeân ewo wezzewunk tahnoôche?
That all men fhould fpeak

$A n$. Ne wame rénnauwunk pàhke ruwaûauk of himfelf and of the good. wutche God nagum, quah waúwerrégix aiak-
things quiiks wutche God, wutche úttarwefanúnguefóunk 


\section{[48]}

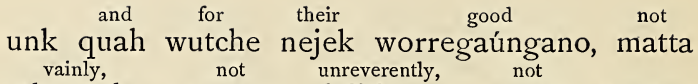
tahnoôche, matta ukffchawe, matta uttamunprofitably.

bafioúngane. 2. King: I. 3 : Levit: 1 о. $3: \mathcal{F o b : ~} 36$. 24. I Cor: 10. 31: Fob: 5.27 :

Deut. 8. I 8: Fer. 2. 30: Levit: 26. 2: Heb: 4. 2. What is the fourth Commandement?

$\mathrm{Qu}$. Chawgun youhwe pákkadtawawunk?

Remember

the Sabbath day

$A n$. Kómmeqúantufh nókkommowunk, [keto keep it holy,

weenâuwunk] wauwertaúun, [perrtâuun] nukSix dayes fhalt thou labour and doe kuddafkfhe kéfequaûwe katarkas, quah keîztaall thy workes but the feventh us wame kàtarkàffounganfh: webe nezenfe day is the Sabbath of

fhúgane mutche nokkòmmounk wutche Iehovah thy on that day thou thalt not do ke God youh thùganèterre akquerifhq' chawany work, thou nor thy Son

gun nowèta arkaffowunk, ke matta kenâumônor thy daughter man-fervant, nor maid-

an, matta kattane kowadjan-ren, matta nannofervant nor thy cattel nor thy ôtenukfqua, matta kekopompetúnganak, matta ke ftranger within thy for in peeouchauk rame ke fquonta, wutche rame nukkuddàlkfhe kefequauwe Iehovah keíztâunas heaven, and earth, the Sea, and all kefukq', quah okke, kathannabâug quah wame
things aiakquiiks rame nejek appôop, quah akquarkazfous 


\section{[49]}

fous [wúwufínnawus] nezzenfe fhugane: newherefore God bleffed the Sabbath day, wutche Iehovah uttchadchimmóas nokkommoand hallowed it. wunk, quah peirtãwanas ewo. Ex. 20. 8, 9, Io,

I I. E $E$ a. 58. I3. Ne. I3. I6, I 7. What is the meaning of that Commandemant?

Qu. Tah ruzómo youh Pákkattawâuwunk? Q That all fhould reft from An: Ne wame pahke wúufinnamanak wutwork and much more from play che arkaffounk quah aufe wutche mómarrawason the Lord's day that wee may fowunk rame Iehovah kéfekut, ne neaûwun hom draw near to in good works notâuchemen re God rame wauwerrègíx arkasfoúnganfh. Efa. 58. г 2, I $3 . \quad 7 a m .4 .8$. What is the fifth. Commandement? Qu: Chazugun nàppachôffit pàkkadtawâuwunk? Honour An: Hokkreztâus [konkreztaus] koufh quah kenoûnunk ne kokonkefeketufh hom quonaious in the land which the Lord thy giveth thee. 1keje okkeik teou Iehovah ke God kummèquun.

Exod. 20. I 2. Who are called thy father and mother? $\mathrm{Qu}$. Auwánnakà)fweraukkoufh quahkenóununk? $A n$. Wame tôukrètaffejek ten chíppakòmthe fchool mûkutchaug, tahattere kôodammochâwunk rain Church or in the commonme maûwewhèkomunk nux afoûdummauwúng-

D anak 


\section{[50]}

wealth.

(I Kin. 5. 13: 2. I2. I Cor. 4. 15.

anak terre. 2. Chro. 29. I8. Pro: 23.22. What is the honour to Superiours?

Q. Chawgun kokkreztâuotounkre toukretafJejek? Reverence,

Obedience,

$A n$. Wawhúngachàmuk waûweztàmmewunk and when I am able recompence.

quah [ne tabafean] rambe maugawunk newutche.

Gen. 4. 20, 2 I Mal. 1. 6. Heb. 1 2.9. Eph.6. I. What is the fixth CommandeQu. Chawgun akkòmmedjchoffit Pakkadtawaument? auzounk?

Thou thalt doe no murder.

(I. Tim. 5. 4 .

An. Matta kokkeminchafko. Ex. 20. I3. What means this Commandement?

Qu. Tah ruwamo youh Pakkádtawâuwunk? That wee fhould not fhorten

$A n$. Ne neaûwun pahke matta taíuqùetauóuthe life

or

health

nan pòmpemantàmmewunk ux affummaffowunk of our felves or others

wutche neaûwun hogganànak ux unkâtagganak but preferve both.

webe koukedjtâunan nefe. Mat. 5. 22. 2 Cor.

7. Iо. Mark. 3. 4. I Sam. 26. 20.

What is the seventh Commandement?

Qu. Chawgun ne faufak pakkadtawawauwunk? Thou fhalt not commit Adultery.

An. Matta komammôfo. Ex. 20. I4. Gen.

9. I0. Levit. I8. 24.

Qu. Chawgun matcherèwunk youh quoteten?

$A n$. 


\section{[5I $]$}

An. Matchtawn hógganának, $\begin{gathered}\text { To defile } \\ \text { with }\end{gathered}$ uxclean uthkatágganak weeche wápafquâwe chiffhegewúnganth

\section{Q. Charegun youh Pákkadchimmeden? \\ Q Chaftity to preferve our} An. Mianumbâuunk, konkfanttawn neauwun bodies in holynes and honhogganának peaiówunganak quah hókkrezour.

tauetoúnganak terre. Titus, 2. 5. I Pet. 3. 2.

I Thes. $4.4,4$.

What is the eight Commandement?
Qu. Chare gun fwankfhit Pákkadtawaudurwunk?
Thou halt not fteal. An. Matta kommôotakon [matta kekomôoto.] Exod. 20. I 5 .

What is the ftealth here forbidden?

$\mathrm{Qu}$. Chawgun kommôotewunk youh quotéten? To take away another man's goods with-

$A n$. Mamman únkatak ren mámachífe, maout his knowledg, without his gift, or to ta waughtauôkq'; matta maugaûkq', ux ókkefpend our own goods without pro. tawn kòmamachìnafh matta wutche kótamfit to our felves or others gaine báficoiánanfh, ux únkatágganak ótambáfíonánâuưh. Luk. 19. 8. I Thes. 4. 6. Pro. 2 I. 20. As Bad 8 Indians

Netátup mámttambáujek éanfketambaugh ókdo fpend their eftates when they want whores ketáwnau mamatteînch nôotch-fquahahìttít quah 


\section{$\left[5^{2}\right]$}

and play at frawes.

quah ókkezhíttìt,

What is here Commanded?

Qu. Chawgun youh pákkádchimmeden?

An. Waûwerre mefínnaman nómamachínãfh well to keep and well to ufe wauwérre wádchanaman quah wauwérre aínas them.

youfh. Pro. I3. I1. Fohn, 6. I 2. Luke, I9. I6.

Q. Chawgun páfakogunfhe pakkadtawauauwunk?

Thou fhalt not beare falfe witnefs againft

A. Matta ketaíantekíawaúghua kechánchethy neighbour.

támmuk re. Exod: 20. I 6.

What is the finn here forbidden?

Q. Chawgun mátcherézennk youh quotéten?

$$
\text { To ly falfely, to think }
$$

A. Okkejâulkin aíantekámpâuwe, roytámmin nux ruwan chawgun matta wérramamóof our felves or others.

muk wutche neaûwun ux únkatágganok. Eph.

4. 25. Fer: 9. 4, 5. Fo/hu: 9. 22. Pro. 13. 7.

Q. Chawgun youh pakkádchimmeden?

$$
\text { Truth and faithfullnefs. }
$$

A. Werramáwunk quah mutchifúnkombane.

[fónkkombauunk] Eph: 4.25. Mat: 23. 23. What is the tenth Commandement?

Qu. Chawgun paíákhe pákkadtawauâuwunk? 


\section{$\lfloor 53\rfloor$}

Thou fhalt not

covet

A. Ahque kíttechowontámmis tahnôoche the houfe of thy neighbour, Thou week wutche kechánchetámmuk, ahque kéttefhalt not covet the wife of thy neighchowontámmis werógen wutche kechánchetambour, nor his man-fervant, nor his maid-fervant muk, matta ewo wajan-ren matta waian-fquah, nor his ox, nor his affe, nor matta wutóximoh, matta wuttáffimoh, matta any thing that is thy neighbours. chawgun nowèta wutche kítechâme. $E x .20$. I 7. What is the coveting

here for-

Q. Chawgun káttauachófjowâwunk youh quobidden?

téten?

Luft after other

A. Káttauachoffowáwunk wutche únkatak mens goods, and want of ren mámachife: quah queraûhíkkowunk wutche contentment with our own etatábrawahittewunk weeche néaûwun nómamaftate.

chínanfh. Heb. 13. 4. Rom. 7. 7.

$$
\text { Whether have you kept }
$$

all

Q. Nammuk pahkodjé kattabrerèanas wame these Commandements?

neijh pákkadtawaâuwungan $h$ ?

A. Matta, ne quah wame rénnawauk máfinners.

matcherêjek. Ro. 7. I 4. Ro. 3. 23.

$$
\text { What is the wages }
$$

Q. Charugunhe inquatâuretounk wutche matinn? cherézunk?

$$
\text { D.3. }
$$




\section{[54]}

Ans: Nuppóunk quah michéme konkejáptorment.

penaûwunk. Rom. 6. 23, \& 2. 8, 9.

Q. Townène kofámbattámen kejahéan?

Onely by

Ans. Webe fpe Jefus Chrift.

$$
\text { Who is called }
$$

Qu. Auwninnah áffowe Fefus Chrift?

The eternal fon who

$A$. Michéme wonnéjon wutche God auwun

for our fakes, became man, that wutche neaûwun hogganának moh renôowus, ne he might redeem and fave us

ewo hom mánnôhikquenan quah kéjáhikquenan. Hoze doth he redeem and

Q. Tunre Fefus Chrift manuôhikquenan quah fave us? kejâhikquenan?

By his righteous life,

Ans. Spe nágamo fonkkómbough kejâuwunk and better death and glorious quah wéfekun nuppówunk quah àrwenungaut refurrection againe to life.

rambeompkéwunk wunk kejaûwunganak re.

Gal: 4. 4. Mat: 5. 20, 28. Pfal: 2. 7, 8. Rom.4.25. How came you to have part, and

Qu: Tun gooje kotâhean chanchepaiewunk, quah felloweship with chanchíawunk weeche Fefus Chrift rame ewo nupDeath and his refurrection? pôunk quah ewo rambeompkewninganak terre? Ans. Spe milkégowunk wutche ewo kékatokau 


\section{[55]}

word

and

Spirit

which

tokaûwunk quah Rafhâuwunk, youh paffoûhikbrings us to and keeps us quenan re Jefus Chrift, quah quowâdchanhik quein him.

nan rame ewunk terre. Foh: I7. 20. I Cor. 6. I7. What is his word?

Q. Chawgun nágamo kékatochâuwunk?
The holy
Scriptures
God
pen-

$A$. Peaíous wufkwhéganfh Jehovah wufkned by the ancient minifters of his word called

uttuwauwunk affwérauk Prophetts \& Apoftles, the old and new Teftament, nâhnekónne quah wuski Nókothommâuèten, the Law, and Goopel. pâkkadtawauaûwunk quah wérranjemokauweten. 2 Tim. 3. I 5 , I 6.

How doth the minifry of of the
Queft. Ten re attabawâuwn wutche pakkad-
bring you towards

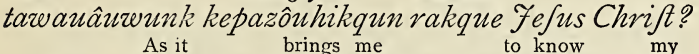
Ans. Arra nopazôuhìkqun waughhéan nofinn and the wrath of matcheréwunk quah wezkéfowunk wutche God towards mee for it. Rom. 3. 20. Gal. 3. 10, 24. ne rakque ne wutche. Rom.7.9, Io.

$$
\text { How doth the knowledge of thy fin }
$$

Qu. Tenre waughtâuwunk wutche komatcheré-

$$
\text { bring you towards }
$$

wunk kopazôuhikqun rakque Fefus Chrift?

$$
\text { Thereby I come to feele }
$$

Ans. Youh fpe ne nopé mequìnneman ne

$$
\text { D.4. }
$$

nan- 


\section{$[56]$}

curfed

eftate,

and

nânnapúmmuk arrachoffewâwunk, quah queneed of Saviour.

râubíkkowunk wutche kékejahuad. Gal. 3. IO, 24. How doth the Minifrye of the

Queft. Ten re attabbowâwunk wutche werranGospel help you in this

jemokâuweten ketàmamungqun rame youh tattaaicursed Eftate?

nüpooiretâmmuk arrachófjewâzwunk?

It humbles mee yet more,

and then

Ans. Womârrumhíkqun naraufe, quah néne rayfes mee out of this miferable tomkêhíkqun wutche youh kónkejappenamuk eftate.

arrachoffewâwunk. Luke. 3. 4, 5, 6.

$$
\text { How doth the minifrie }
$$

Qu. Ten re kokkôudumchâuwunk wutche werthe Gospell humble you more? ranjemokâuweten kowómarrumhikqun wunk?

By revealing free . Spe môukinnamowunk wutche narrauwe wômarretoúnk wutche Jefus Chrift Becaufe he dyed to fave fin-

2 Tim: r ı. ro. Waje nuppóus kejahèan mamatners : and yet concherèjek; Foh. I6. 7, 8. 6. 44. Quah narra nowauvincing mee of my finn becaufe I betaûhikqun wutche nomatcheréwunk, waje matta lieve not on him, and of my utter nenôftammôan nkejé ewo, quah michéme noinfufficiency to come to him. monúnquefówunk peaûwun ewounk re; Luke, I9. Io. Quah rió nenomequínnaman ne hok miche 


\section{$[57]$}

utterly loft.

chéme tanhich.

How then doth the minifry of the

Q. Ten néne kokkôudumohâuwunk wutche Gospel rayse you up out of werranjemokâuwunk kótantanttamhikqun wutche that lof efate to come to youh anhémuk árrechofjewawunk pean re Jejus

Chrift?

Ans. Nenar nekokkoôdummohikqun raû- value and the virtue of the death weto quah milkefewunk wutche nuppówunk of and the riches of wutche Jefus Chrift, quah pâuafoúnganfh wutche his free love to loft finewo narrauwe wómârretowúnk re anhéjek maners; macheréjek foh. I 2. 32, 2 Cor: 5: I7, 20, môuveales

\section{the promife} of fkefhaddawn kroûdemâuwetowúnk wutche grace to fuch, and minifters werríttepantammewunk re youjek, quah merâh peaio rafhâuwunk wutche wérrettepantamme$\underset{\text { his }}{\underset{\text { wonk }}{\text { to aply }}} \begin{gathered}\text { and } \\ \text { promife }\end{gathered}$ nagamo kroûdamauwetounk wutche wérrettepantammewunk re nêan hok, quah nowadme in him.

janhikqun rame nagum. 2 Pet: 3. I8, Luke I9. ıо, Mat: 9. I3, Gal. 3. 5, Ro Iо. I7, with I. I6. Queft, 


\section{$\left[5^{8}\right]$}

How doth the Holy Spirit of Grace

Qu. Ten re peaio Rafhâuwunk wutche wèrrithelp you and bring tepantámmewunk kùtamamauhikqun quah pazôuyou to and cause improve hikqun re Fefus Chrift, quah miffnnamahikqun nâgamo krôudamauwétounk, quah kowadchankikin him?

qun ewounk terre?

By begetting in me

Ans. Spe rikhéan [tikhéan] rame ne wârremattâmmewunk àttummanah ewo: $R o$. Io.

I 7. I0, I4. Zec: I 2. IO. prayer to call upon him,

Attabbowawunk wewhékum fkeje ewo: amban-
Repentance toetammewunk môuwun rakque ewo, quah new obedience to ferve him.

w'lkio weztammewunk kretammin ewo. $R o$.

I6. $25,26.2$ Cor. IO. 4,5 .

Q. Chawgun atta Warremattammewunk?

Faith is a grace

Ans. Warremattammewunk arta werrîttepãof the holy Spirit;

tammewunk wutche peaío Rafhâuwunk; Phil:

I. 29. 2 Cor. 2. 4, I 2. Nahwutche hókkeje-

1. 29. $2 \operatorname{cor}_{\text {myfelf }}^{2.4}$ and 2.4 believe waûghtam ne hok quah warremattam fkeje Iefus Chrift wutche funkkómbaûwunk quah micheme ke- 


\section{[59]}

life;

kejâwunk ;

\section{Queft. Chawgun attâbawawunk?}

Prayer is a calling

Ans. Attâbowawunk wewhékechaûmewaupon in the name of

wunk wulkêje God rame wézewunk wutche Ieby the help of the holy fus Chrift fpe aínamaûetowunk wutche peaío Ghoft according to the will of

Rafhaûunk nouffe utteoitammewunk wutche God. (Joh. x. 5. 14. God. Mat. 6. 9. Foh. I6. 23. Ro. 8. 26, 27. How did teach his

Qu. Ten Fejus Chrift kokoodumchauwus ewo difciples to pray?

nannawunnakuts attaboan?

Thus.

Anfw. Rio.

Our father

in heaven

Hallowed

Noûfhin

aûfequamuk terre

wérrettepanbe thy name

tammunatch [wòweztâuonatch] kowéfewunk

Let come thy Kingdome, thy will

Peamoutch' kúkkuffootúmmowunk, kòrantàmbe done on earth as in Heaven

mowunk neratch fket'ôkke nenar âufequamuk Give us our dayly

terre, Mèfonah èa kèfuk kónkefekatứh nofood,

méetfounk, [petúlkkenêag]

Forgive us

nomàtchereúngananfh nenar tàkquantaminan

them

$$
\text { that trefpafs againft us, }
$$

Akquantamínah

ewojek nomàtcherehéaqueàguk, Afquonfàkkon-

gonan 


\section{[60]}

$\begin{array}{ccc}\text { into } & \text { temptation, } & \text { but } \\ \text { gònan } & \text { mitchemôuretounk, } & \text { webe } \\ \text { deliver us } & \text { from } & \text { evill, }\end{array}$ kûppoquohwhèriggamínah wutche madjk' wutthine is the Kingdom, and the Power, che kèkatah kètaffootómoonk, quah milkèffoand the Glory, for ever

wunk quah àíttarwejanúnguefówunk michème and for ever; Amen.

quah michème: $\mathrm{Ne}$ râtch.

Qu. Chawgun Ambantoietammerunk?

Repentance is a grace

A. Ambantoíètàmmewunk wèrrìttepantamof the holy Spirit, whereby mewunk wutche peaió Rafhâuunk nah wutche I loath my finnes and ne nezkòntum nomàtcherrewúnganfh quah nezabhorr myfelf for them, and confers kàrraman m'hok yous wutche, quah nòrremâthem before God and mourn hitch nèíh arquabit Jehovah, quah nomâuafter for the pardon wetepaz noufe Jefus Chrift wutche akquanteof them, and for grace màueten wutche nêilh, quah wutche wèrrittepanto ferve him in newnefs tàmmewunk wùttufomôan rame fkiàwunk of life.

wutche kejâuwunk. Acts, 5. 31. Fohn, 24, 20.

Levit. 26. 40, 41. Pro. 28. I3.

What is this new life, or Qu. Chawgun youh wufkio kejâuwunk; ux obedience? wâweztàmmewunk? 


\section{$[6 \mathrm{I}]$}

A. Wufkèawunk wutche kejâuwunk arta a grace

of $\mathrm{y}^{\mathrm{e}}$ holy

Spirit

wèrrettepantàmmewunk peaiò Rafhâuwunk whereby

I forfake my former nah wutche nenogottûmmonufh ne negònne lufts and vain company chachífhfeúnganfh, quah akôuwa chanchiawunk, quah pummèan arquabe Jehovah rame
the light wequàai wutche ewo uttuwâwunk, quah wâuthe Communion of the Saints. wèrrechànchìwúnganak terre wutche paperrisfejek. Pfal. 51. I, 2, 30. Rom. 7. 6. I Pet. 4. 2, 3, 4. Pfal. x16. 9. I19. 9. Pfal. I19. 105. I, 15. Pfal. 16. 3.
What is
the Communion

of

Qu. Chawgun wàuwerrechánchiawunk wutche the Saints?

papervifjejèk?

A. It is the fellowip of the Church Wauwerrechanchiawunk wutche mân wewhèkomúnk Rafhâuwàndowe wàuwerègaof the Covenant of nak terre, wutche wèrrawâuunk wutche wèrGrace and the Seales rittapantammowunk, quah wôhpretàmmowúnthereof.

ganfh youh wutchio. I Cor: I. 2. Phil. 1. 5. Act.

2. 47. Rom: 9. 4. I Cor: I 2. 13.

What is the Church?

Qu. Chawgun mâuwewhékomuk?

A Congregation of Saints joyn-

$A n$. Mâuwêwunk wutche paperíffeiek waû- 


\section{$[62]$}

ed

together in

the Bond

of

weioffemuk nappe rame wôhpretewunk wutche the covenant, to worhip God and wetampaddawunk, routaffen Jehovah quah kókkekòodamàuwetúmmen rame wame ewo good ordinances. werréganak pakkadtawauwúnganak terre. Pfal. (1 Cor. 14. 23, 26. 89. 5. Ps. 50. 5, I6. Ezek. 20. 37. Act. 242.
What is the Bond of the co$\mathrm{Q}$. Chawgun woprétounk wutche wetampad-
in which in dewunk rame youh Mauwéwhékonunk wâuioyned together?

weja/femuk nappe?

$$
\text { It is the profeffion }
$$

of

that Cove-

$A$. Wárremahittewunk wutche youh wètamnant which hath made with his pàddewunk teou God keíztâunas wêeche ewo faithfull people that he will be funkòmbâueritch nketâmbâmh ne ewo bitch a God to them and to their feed. omando Jehovah re nejek quah re nejek antfejek. e2 Cor: 8: 5 \& 9: I 3. Gen. I 7: 7 his

Q: Re Chawgun Fehovah wôpréaut wîfketambàmh rame youh wetampaddaweninganak terre? To give up themfelves and their
Anfw. Mâuganau hoggaûoufh quah neiek
feed antfèíek, negonne re Jehovah ne hom neiek become his people.

(2 Cor: 8. 5 . ewo wòlketambamanak. Fofh. 24. I 5, 2 I, 24, 25 . 
and then to the Elders

and brethren quah nène toûkretàffeiek ne quah memattidof the Church to forward dewôak wutche mauwewhèkomunk negonfhidthe worhip of and their dawn roútauaúwunk wutche God quah neíek mutual edification.
( $\mathrm{w}^{\mathrm{t}}$ 10. 28, 29 to 34 . kòkkokôudemàuetúmmechâwunk: Nehe. 9. 38. How do they give themselves up and

Qu. Ten mauganau neiek hóggauwauwo quah their feed to

neiek antfeiek re Jehovah?

By receiving through faith

An. Spe àttummemimmewunk fpe wàrreAn. and mattàmmewunk Jehovah. Fohn, I. I 2. quah ehis Covenant to themfelves and wo wàtampàddewunk, re hoggaûauk quah neiek tànfeûnganak re, Gen: I 7. 9, Io. quah nècordingly walking themfelves

nar wótterainaínauh hoggâuwo, Ifay, 56. 6, 7 . and trayning up their children in the quah koûdamâuóak omúkkràmuk màiawúnganak terre wutche ewo wetámpàdewunk. Gen:

I8. I9.

How doth they give up themselves and their Q. Ten mâuganau hóggauâuwo quah nejek mukkraauk re tôukretaffejek quah wémattiddewo-
of the Church?

ak wutche mâuwewhekomunk?

A. Spe fúnkowauwunk wutche neiek matche 


\section{[64]}

Sinnes and profeffion cherewúnganfh, Mat: 3. 6. quah wâuwerremahíttewunk wutche youhiek wárremattamewunk and of theire fubiecti2 Cor: 9. I 3 ; quah wutche neiék noûfferewahuon to the Gorpel of wâwunk re mòrraniemokaûwunk wutche Jefus and fo they and theire children Chrift quah rìo neiek quah neiek mukkrâauk are received into the fellowhip attúmmonummóauk rame re chanchìawunk of the Church, and the feales wutche maûwewhèkomunk quah wôpretoúngthereof. anfh youh wutchio.

What are
$\mathrm{Qu}$ the Chales
Covenant of tampàdderennk èo rame àkquinnagàtte wutche the Gospel
wèrraniemokä̈rwunk wutche 7 fus Chrift?

$$
\text { Baptifm and the holy Supper }
$$

$A$. Kitcheffumòunk quah peaiò nènepòm(2. II. I. to II. 25.
of pomuk wutche Jefus Chrift. Ro: I4. I I. with Col. What is done for you in Baptifm?

$\mathrm{Qu}$. Chàwgun kekeiftanfh kitcheffumoùnganak terre?

An. Rame Kitcheffumònk kitzfúmmodean with water is a fign and wêeche nippe arta wâuwanúnquot quah wôhfeale of my wanhing with prètounk wutche nukkitzfommachaûwunk weeche 


\section{[65]}

the blood and Spirit $\quad$ of
che népuk quah rafhâuwunk wutche Jefus Chrift Rom. 6. 2. Act. 22. 16. Quah youhfpe wutche my ingraffing ne ankwhótewunk [állequataûwunk] ramére Jefus Chrift: wutche akquántemaûetounk quah cleanfing of my finnes:

kitzfimmoden wutche nomátchereúnganfh: Luk. of my rifing up out of af3. 3. wutche ne tompkéwunk wutche fewayfliction. támmoúnganfh: I Pet. 3. 20, 21. Quah nànak of my refurrection from wutche ne rambe-ompkínnawunk wutche nàbthe dead at the laft day.

bajek attâjauche kéfekutt. I Cor. I5. 29. What is done for you in the fupper

Qu. Chaugun kekeîftaufh rame nenepómpomuk wutche Fefus Chrift? affreidam the Lord's Supper. Ans. Rame peaío nenépómpomuk wutche Jefus Chrift the receiving of $\begin{gathered}\text { of } \\ \text { broken }\end{gathered}$ and whentche petúkqunneg quoquàfqúenaman, quah wine fôkennúmmen, I Cor: 10. 16. Mat: 26. 26, 28. Foh. 6. 55. mutche figne and feale of my waúwenúnquat quah wôhprètounk wutche ne reeeiving communion of the body tínnamounk wâuwerrechànchine wutche hok of broken wutche Jefus Chrift fukquúnnaman [quoquàsque 


\section{$[66]$}

for me.

And $\underset{\text { of }}{\underset{\text { quénaman }}{\text { his }} \text { wutche ne, I Cor: I 2. I 3. Quah }}$ wutche nagum népuk pòke-fhínnaman wutche me; and thereby of my growth [in] ne; quah youhfpe wutche né anchégowunk raof the pardon and me Jefus Chrift wutche akquantemaûeten quah fealing of my finnes;

kedjhittewũk wutche nomatchereúnganóas ; wutthe fellowipip of his holy

che waûwerrechanchiawunk wutche ewo peaío Spirit ;

of my ftrengthning

Rafhaúunk wutche ne mílkechâuwunk [mílketauaûwunk quah tauchêgowunk wérrittepangrace and of my

tàmmewûnganak terre: quah wutche ne napfitting together with uppewétappomowâuwunk wêeche Jefus Chrift fkeon his throne of

jé ewo àrwenúnquat ahapáppomuk wutche atglory at the laft Judge tàrwejauúnquefówunk uttâjauche waffúmmoment.

wauwúnganak terre.

What is the refurrection from

Queft. Chawgun rambe ompkérunk wutche the dead, which was sealed up nuppoìnganak, têou moh wôhpretowâuwus [milke-

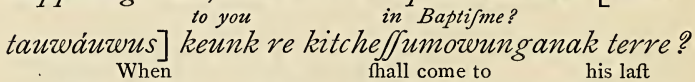
'Anfw. Jefus Chrift péant' nagum uttátauche Judgement ;

All that wáffimiddewúnganak re, Foh. 5. 28, 29. Wame 


\section{$[67]$}

are in the grave fhall rife againe both warrekáffejek bitch rambe ompkèwunk takque the juft and the unjuft. fonkkúmbaûjek quah mámattambaujek. Act. 24. What is

Qu. Chawgun uttájauche waffùmmowàwunk téwhich is fealed up ou milketàuwo [wohpretauwo] ke rakque rame ne-
the Supper

to you in nepómpomuk wutche Zefus Chrift afjèdam Lord's

Supper?

At the laft day $A$. Uttàjauche kéfuk keaúwen wâme bitch appeare before the Judgement feat moufkemen arquàbe waffemíddemuk ahappopeof
an account Jefus Chrift 2 Cor. 5. Io. merân okkêehtâffowunk wutche neaûwun airkaffowunand to receive our regananfh quah miffínnaman neaûwun únquetaûeward according to them.

tounk yous nouffe. [neuar râuato àrrüt wutche.]

Mat. I 2. 36. I Cor. 4. 5. Eccl. I 2. I 4.
What is
the reward
that fhall then

Qu. Chawgun unquetauetóunk teou bitch nène be given?

mèrriten?

The righteous fhall goe into ever-

$A$. Sunkómbaûjek bitch aug micheme kejâulafting life, and the wicked fhall be ùnganak re, quah mámattambaûjek bitch pokkincaft into eternal fire with the Devill naûauk rame re michéme rowtag wêeche Chêpi and his Angells. quah ewo Angellôag. Mat. 25. 34, 46. 

- 



\section{SOME HELPS FOR THE INDIANS:}

\section{A CATEOHISM,}

BY THE REV. ABRAHAM PIERSON.

WITH AN INTRODUCTION,

BY J. HAMMOND TRUMBULL.

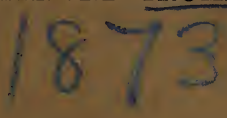



Microfonnat ay

Presenumion

Sovires

m保 6513.01

30 DCT 95 


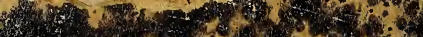 \\ (t)}

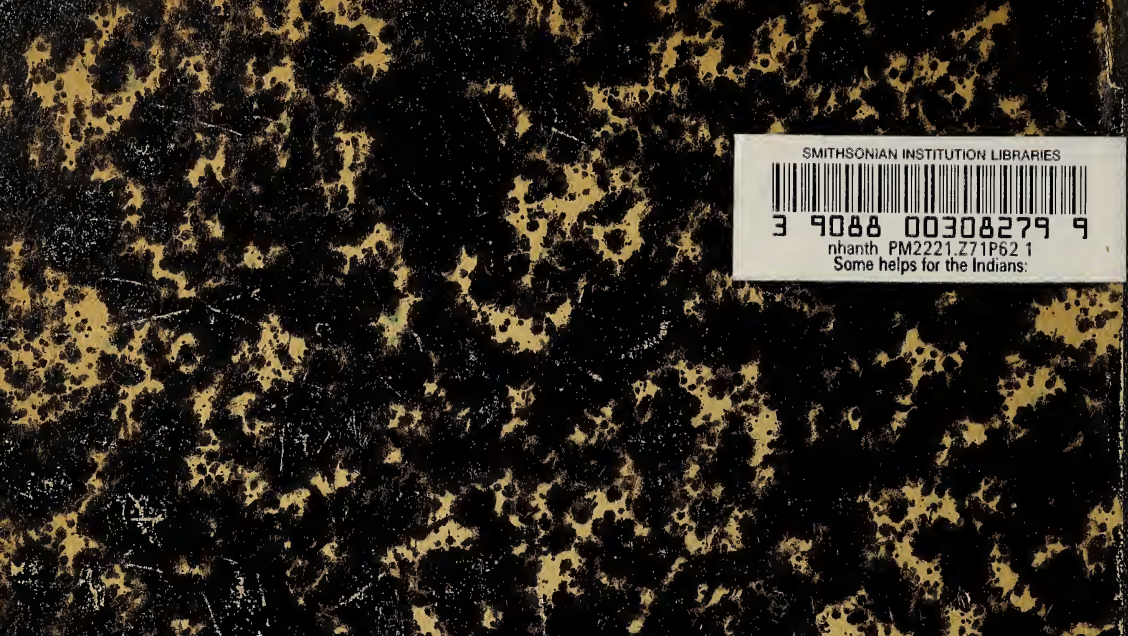

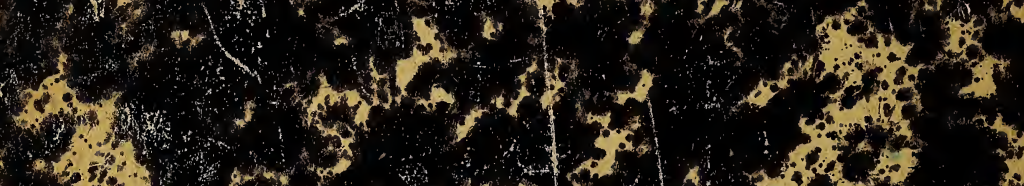

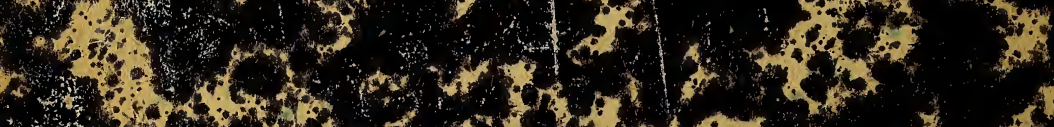

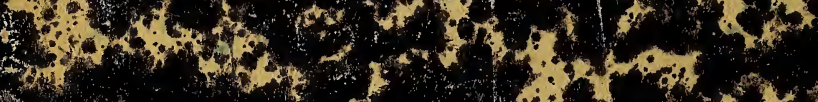

.

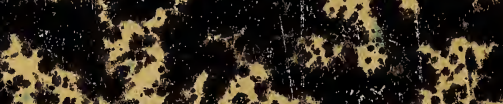

Q. 40

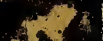

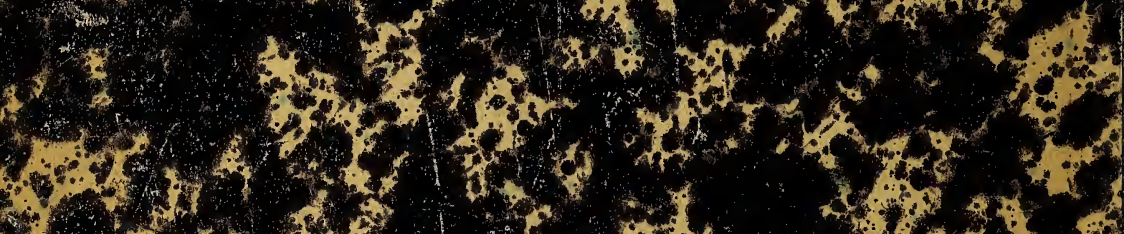

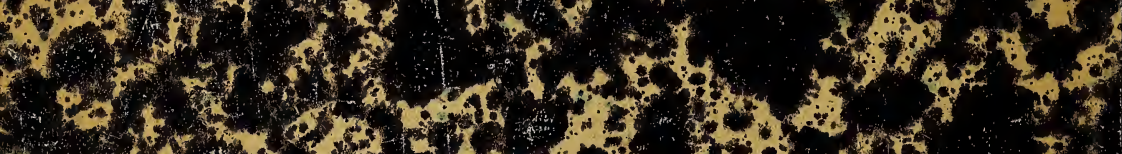

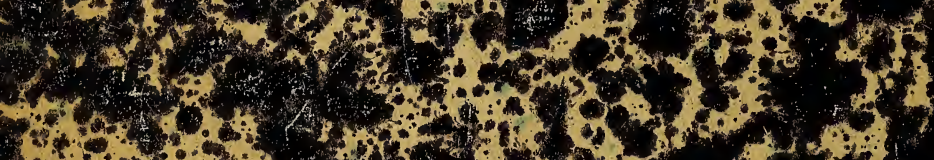

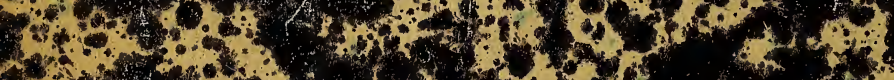

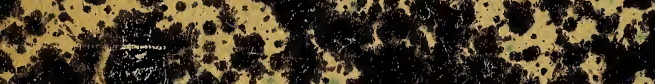

c. a.6.

the

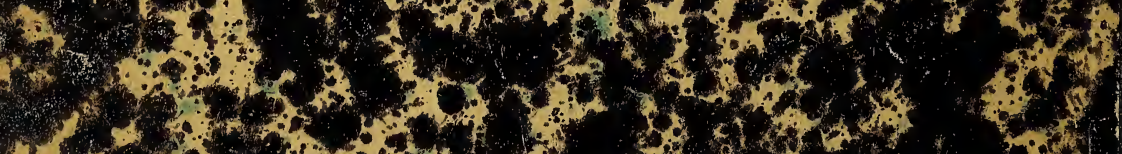

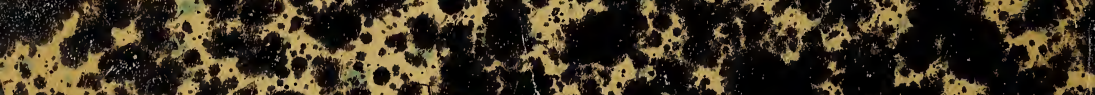

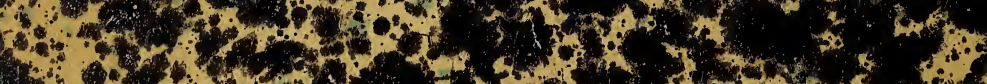

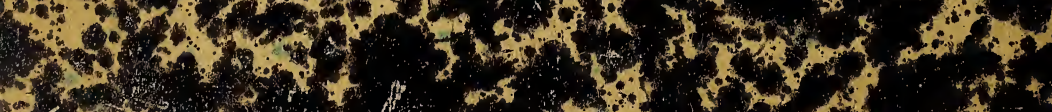

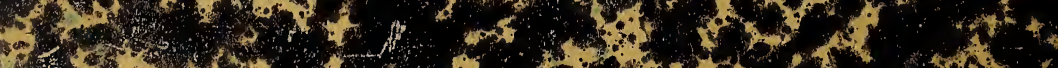

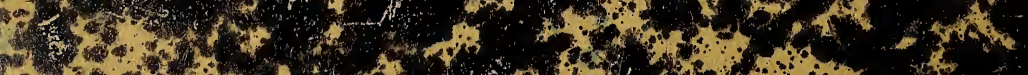

